FABIANA MENDONÇA MARTINS DE ALMEIDA

Disciplina jurídica da companhia aberta:

objeto, estrutura e fronteiras

Dissertação de Mestrado

Orientador: Prof. Associado Dr. Eduardo Secchi Munhoz

UNIVERSIDADE DE SÃO PAULO

FACULDADE DE DIREITO

São Paulo - SP

2020 

FABIANA MENDONÇA MARTINS DE ALMEIDA

Disciplina jurídica da companhia aberta:

objeto, estrutura e fronteiras

\begin{abstract}
Dissertação apresentada à Banca Examinadora do Programa de Pós-Graduação em Direito, da Faculdade de Direito da Universidade de São Paulo, como exigência parcial para obtenção do título de Mestre em Direito, na área de concentração Direito Comercial, sob a orientação do Prof. Associado Dr. Eduardo Secchi Munhoz.
\end{abstract}

UNIVERSIDADE DE SÃO PAULO

FACULDADE DE DIREITO

São Paulo - SP

2020 



\title{
Disciplina jurídica da companhia aberta: objeto, estrutura e fronteiras
}

\begin{abstract}
Dissertação apresentada à Banca Examinadora do Programa de Pós-Graduação em Direito, da Faculdade de Direito da Universidade de São Paulo, como exigência parcial para obtenção do título de Mestre em Direito, na área de concentração Direito Comercial, sob a orientação do Prof. Associado Dr. Eduardo Secchi Munhoz.
\end{abstract}

Banca Examinadora:

Orientador: Prof. Associado Dr. Eduardo Secchi Munhoz Universidade de São Paulo

Examinador(a):

Examinador(a):

Examinador(a): 

Catalogação da Publicação

Serviço de Biblioteca e Documentação

Faculdade de Direito da Universidade de São Paulo

Mendonça Martins de Almeida, Fabiana

Disciplina jurídica da companhia aberta: objeto, estrutura e fronteiras ; Fabiana Mendonça Martins de Almeida ; orientador Eduardo Secchi Munhoz -- São Paulo, 2020.

360

Dissertação (Mestrado - Programa de Pós-Graduação em Direito Comercial) - Faculdade de Direito, Universidade de São Paulo, 2020.

1. Companhia aberta. 2. Mercado de valores mobiliários. 3. Registro de emissor de valores mobiliários. 4. Categorias de registro. 5. Dispensa de registro. I. Secchi Munhoz, Eduardo, orient. II. Título. 



\section{AGRADECIMENTOS}

Os caminhos da vida me levaram do Rio de Janeiro para São Paulo, dos Pilotis para as Arcadas. Para o Largo de São Francisco, não sem motivo.

Com a viva lembrança de momentos e lições que tanto inspiraram e iluminaram o caminho até a conclusão dessa etapa, dedico meus comovidos agradecimentos:

Ao Professor Eduardo Secchi Munhoz, com imensa gratidão pela acolhida como orientanda e monitora, pelas importantes lições e pela sempre alegre e engrandecedora convivência.

Ao Professor José Alexandre Tavares Guerreiro, pelas preciosas colocações feitas em minha banca de qualificação, pela riqueza do convívio na Faculdade e em seu prestigioso grupo de estudos, e ainda por me recordar de Miller e de Baudelaire. Também aos amigos e mestres que o grupo de estudos reúne, pela estimulante e valiosa troca, em especial nas pessoas de Gabriel Buschinelli e Laura Amaral Patella, pelo constante incentivo.

À Professora Juliana Krueger Pela, também pelas preciosas colocações feitas em minha banca de qualificação, espelhando rara sensibilidade e generosa dedicação. E ainda, em conjunto com a Professora Sheila Cerezetti, pelo inspirador exemplo de liderança e pelas inesquecíveis experiências do curso de "Ensino do Direito Comercial".

Ao Professor Erasmo Valladão Azevedo e Novaes França, com deferência pelas palavras de respeito e seriedade para com a atividade acadêmica que marcaram minha primeira aula nessa casa.

Aos companheiros de pós-graduação, que compartilharam as alegrias e angústias dessa jornada, com felicidade pelos laços cultivados, especialmente nas pessoas de Ana Carolina Weber, Mariana Martins-Costa Ferreira e Maria Beatriz Grella Vieira.

Ao Professor Marcelo Fernandez Trindade, pelas generosas e determinantes lições, na vida, na academia e na prática profissional, pelo exemplo de dedicação e respeito que incute pelo magistério e pela advocacia, e pelo privilégio da convivência, com a admiração de aluna, sempre.

Também em conjunto com os companheiros da Trindade Sociedade de Advogados, Pedro Testa, Philippe Medeiros, Thiago Tannous, André Pitta, João Maion, Lucas Camargo, Bruno de Lara Resende, Gabriela Codorniz, Rafael Salles, Marcos Pinto, Ademar Vidal, João 
Siqueira, Marília Lopes, Luiza de Paula, Ricardo Castorri e Eduardo Oliveira, pelo apoio irrestrito e pelos inestimáveis ensinamentos diários, nesses mais de dez anos de trajetória, com profundo respeito e admiração.

Aos meus pais e também Professores, Gilberto e Patricia, pelas lições mais fundamentais, pelo exemplo de fé e doação e pelo incansável amparo. Também à minha irmã, Victoria, motivo maior de alegria e orgulho, pela cumplicidade. E a Eugenia, pelo apoio constante. A dois grandes incentivadores, Galeno Martins de Almeida e Alirio Lins de Medeiros, por "só coisas boas", com eterna saudade.

Ao meu marido, Philippe, pelo aprendizado diário sobre as coisas mais valiosas e por me apresentar a uma capacidade de amor e companheirismo, de honestidade e lealdade, de devoção e renovação, ilimitada.

A todos, e à velha e sempre nova Academia de Direito, muito obrigada. 


\section{RESUMO}

Esta dissertação é dedicada ao estudo da disciplina jurídica da companhia aberta inaugurada pelas Leis n. 6.385/1976 e 6.404/1976, com foco na identificação de seu objeto e na análise de sua estrutura. Nesse intuito, busca promover uma análise panorâmica da matéria, para então examinar de maneira mais aprofundada as normas legais e regulamentares que escoram as fronteiras dessa disciplina, notadamente $(i)$ as normas sobre o registro de emissor e o registro de oferta pública de distribuição de valores mobiliários, em atenção ao sentido e alcance da admissão à negociação de valores mobiliários nesse mercado, que determina o enquadramento como companhia aberta, de acordo com a definição legal; (ii) aquelas voltadas a tratar diferentemente as diferentes companhias abertas, conforme as espécies de valores mobiliários de sua emissão admitidos à negociação e o seu porte, que erigem fronteiras internas dentro dessa disciplina; e (iii) aquelas que permitem a ampliação do acesso a esse mercado por companhias não registradas como abertas, gerando um movimento quase que de erosão das fronteiras externas dessa disciplina. $\mathrm{O}$ tema adquiriu maior complexidade na medida em que o universo de normas aplicáveis às companhias abertas foi continuamente alterado e ampliado para fazer face à realidade. Deste quadro resulta uma nova e mais ampla taxonomia, que, por sua vez, revela um distanciamento da antiga dicotomia absoluta entre companhias abertas e fechadas que originalmente pautou a definição do objeto e da estrutura dessa disciplina. Espera-se contribuir para a elucidação desse quadro, em especial no tocante aos critérios para enquadramento como companhia aberta, bem como para a promoção de reflexão em torno dos contornos dessa disciplina jurídica, inclusive quanto aos novos caminhos que a ela se apresentam.

Palavras-chave: Direito societário - Direito do mercado de valores mobiliários companhia aberta - admissão à negociação - categorias de registro - dispensa de registro 


\begin{abstract}
This dissertation provides an analysis concerning the legal discipline on public companies, focusing on the investigation of its underlying object and on the examination of its structure, as introduced by Brazilian Laws No. 6,385/1976 and 6,404/1976. In this regard, it initially provides a panoramic overview of the subject matter and subsequently explores cornerstone legal and regulatory provisions that determine this discipline's boundaries, namely $(i)$ the rules on the registration of securities issuers and on the registration of public offerings, with due regard to the definition and scope of the admission to trading on regulated securities markets, upon which the legal discipline governing public company applies; (ii) those designed to adapt the legal discipline on public companies according to the type of securities admitted to trading and according to their stature, thereby establishing internal boundaries within this body of rules; and (iii) those that enable access to regulated securities markets by non-registered companies, ultimately reshaping this discipline's external boundaries. New layers of complexity amassed as the body of rules governing public companies was continually adjusted and amended to address the ongoing reality. A new and more diverse taxonomy arises therefrom, that in turn reveals a departure from the outmoded dichotomy between public and private companies that originally dictated the object and the structure of the governing discipline. Accordingly, this dissertation aims to contribute towards the elucidation of the current legal framework governing public companies, particularly regarding applicable classification criteria, as well as to encourage further reflection on this discipline's overall contours and on the several paths available in this legal field.
\end{abstract}

Keywords: Corporate law - securities regulation - public companies - admission to trading - registration categories - registration exemption 


\section{TABELA DE ABREVIAÇÕES}

\begin{tabular}{|c|c|}
\hline ADR & American Depositary Receipts \\
\hline AMF & Autorité des Marchés Financiers \\
\hline ANBIMA & $\begin{array}{l}\text { Associação Brasileira das Entidades dos Mercados Financeiro e de } \\
\text { Capitais }\end{array}$ \\
\hline B3 & B3 S.A. - Brasil, Bolsa, Balcão \\
\hline BACEN & Banco Central do Brasil \\
\hline BDR & $\begin{array}{l}\text { Certificados de depósito de valores mobiliários (Brazilian Depositary } \\
\text { Receipts) }\end{array}$ \\
\hline CCB & Cédula de Crédito Bancário \\
\hline CEPAC & Certificados de Potencial Adicional de Construção \\
\hline CIC & Contrato de Investimento Coletivo \\
\hline $\mathrm{CMN}$ & Conselho Monetário Nacional \\
\hline $\mathrm{CPF}$ & Cadastro de Pessoas Físicas \\
\hline CPMF & $\begin{array}{l}\text { Contribuição Provisória sobre Movimentação ou Transmissão de Valores e } \\
\text { de Créditos e Direitos de Natureza Financeira }\end{array}$ \\
\hline $\mathrm{COE}$ & Certificado de Operações Estruturadas \\
\hline CONSOB & Commissione Nazionale per le Società e la Borsa \\
\hline CRA & Certificados de Recebíveis do Agronegócio \\
\hline CRI & Certificados de Recebíveis Imobiliários \\
\hline CVM & Comissão de Valores Mobiliários \\
\hline DFP & Formulário de Demonstrações Financeiras Padronizadas \\
\hline EUA & Estados Unidos da América \\
\hline FGTS & Fundo de Garantia do Tempo de Serviço \\
\hline FIP & Fundos de Investimento em Participações \\
\hline FSA & Financial Services Authority \\
\hline IBDF & Instituto Brasileiro de Desenvolvimento Florestal \\
\hline IBGE & Instituto Brasileiro de Geografia e Estatística \\
\hline IOSCO & International Organization of Securities Commissions \\
\hline IPCA & Índice Nacional de Preços ao Consumidor Amplo \\
\hline ITR & Formulário de Informações Trimestrais \\
\hline NASDAQ & National Association of Securities Dealers Automated Quotations \\
\hline $\mathrm{NCA}$ & Nota Comercial do Agronegócio \\
\hline
\end{tabular}




\begin{tabular}{|l|l|}
\hline NYSE & New York Stock Exchange \\
\hline PIB & Produto Interno Bruto \\
\hline SDM & Superintendência de Desenvolvimento de Mercado da CVM \\
\hline SEC & Securities and Exchange Commission \\
\hline SFN & Sistema Financeiro Nacional \\
\hline SRE & Superintendência de Registro de Valores Mobiliários da CVM \\
\hline STF & Supremo Tribunal Federal \\
\hline STJ & Superior Tribunal de Justiça \\
\hline SUMOC & Superintendência da Moeda e do Crédito \\
\hline
\end{tabular}




\section{SUMÁRIO}

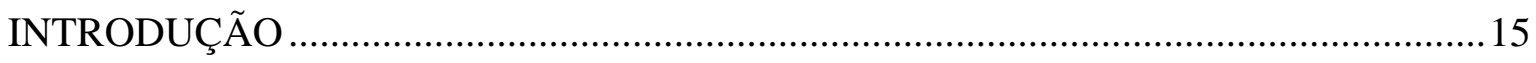

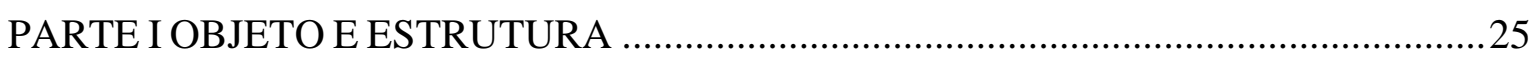

CAPÍTULO 1 A COMPANHIA ABERTA E O DIREITO ...........................................27

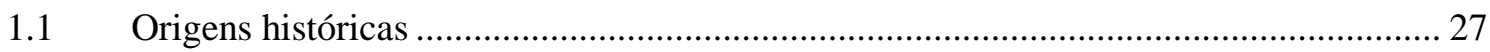

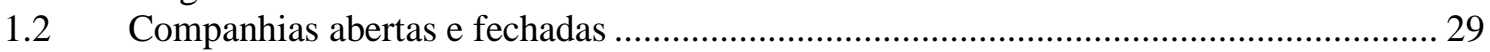

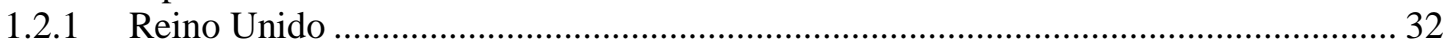

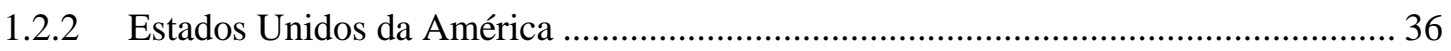

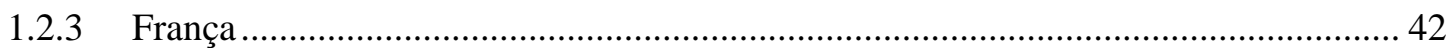

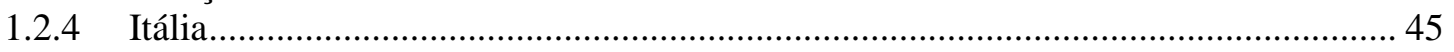

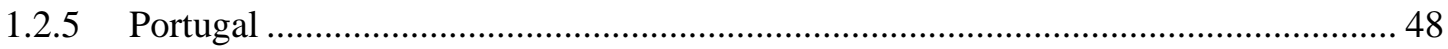

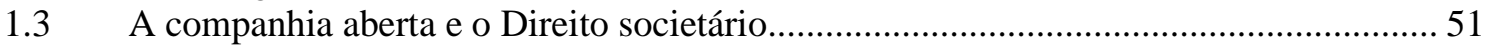

1.4 A companhia aberta e o Direito do mercado de valores mobiliários ..................................55

CAPÍTULO 2 A COMPANHIA ABERTA NO DIREITO BRASILEIRO (I): ANTES DA

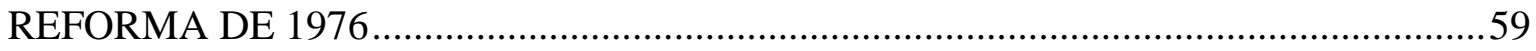

2.1 As companhias e o mercado de capitais brasileiros (até 1976) ….....................................59

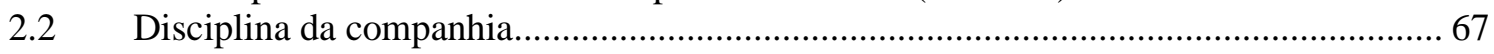

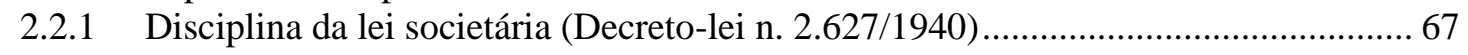

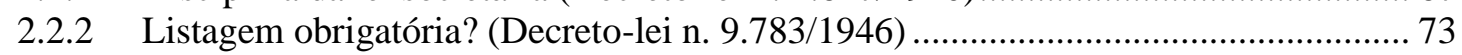

2.2.3 Disciplina complementar da lei do mercado de capitais (Lei n. 4.728/1965) ............ 74

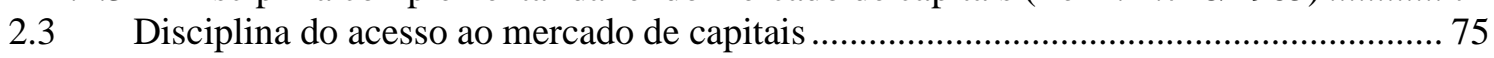

2.3.1 Disciplina da lei do mercado de capitais (Lei n. 4.728/1965) ….................................. 75

2.3.2 Posterior regulamentação do registro (Resolução n. 88/1968) .................................... 79

$2.4 \quad$ Disciplina da sociedade anônima de capital aberto ....................................................... 82

2.4.1 Disciplina da lei sobre imposto de renda (Lei n. 4.506/1964).................................. 82

2.4.2 Disciplina superveniente da lei do mercado de capitais (Lei n. 4.728/1965) .............. 84

2.4.3 Novos contornos (Resoluções n. 16/1966 e 106/1968) ……………........................... 85

2.4.4 Posterior consolidação (Resolução n. 457/1977) ……………………………............ 90

CAPÍTULO 3 A COMPANHIA ABERTA NO DIREITO BRASILEIRO (II): A PARTIR

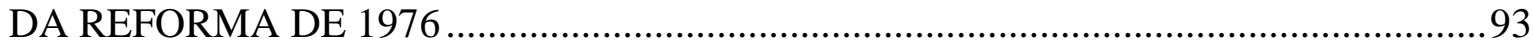

3.1 Disciplina da companhia aberta: o marco legal de 1976 ................................................. 93

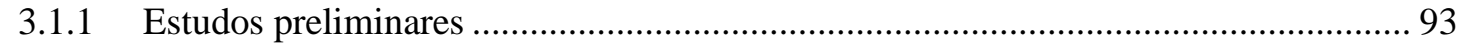

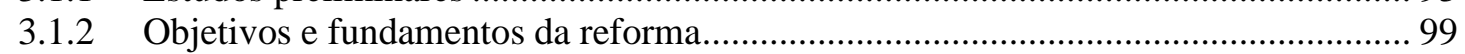

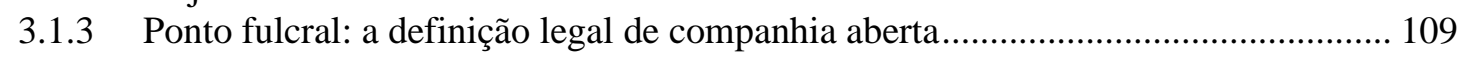

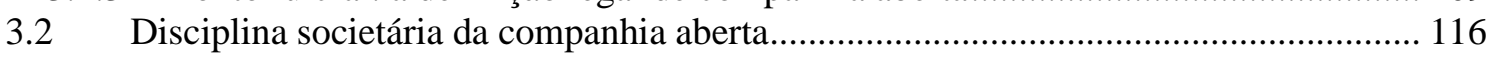

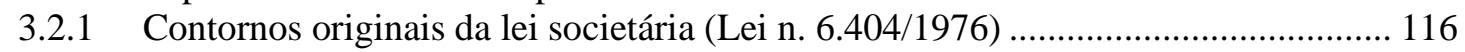

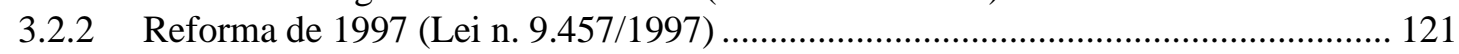

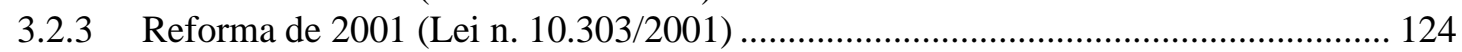

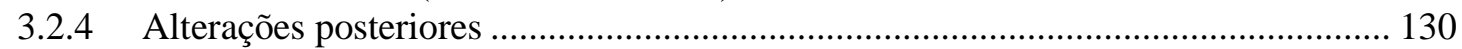

3.3 Disciplina do mercado de valores mobiliários.............................................................. 133

3.3.1 Contornos originais da lei do mercado de valores mobiliários (Lei n. 6.385/1976) 133

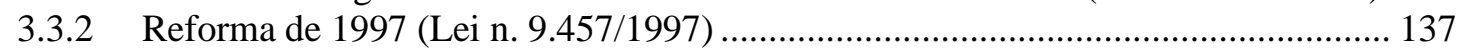

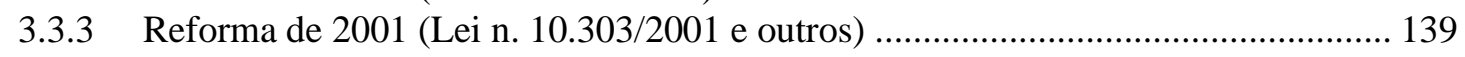

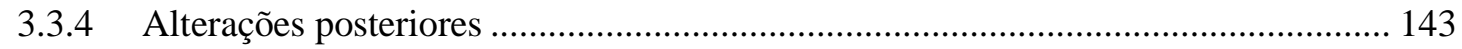

3.4 As companhias e o mercado de capitais brasileiros (após 1976) ..................................... 144 


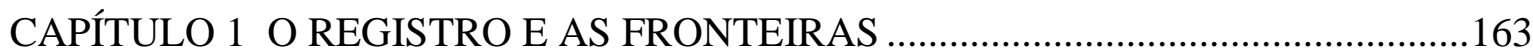

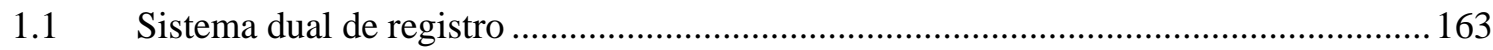

1.1.1 Registro de emissor de valores mobiliários ............................................................167

1.1.2 Registro de oferta pública de distribuição de valores mobiliários..........................176

1.1.3 Listagem e admissão à negociação em mercado organizado..................................182

1.2 Companhia aberta: valores mobiliários "admitidos à negociação”? .............................187

1.2.1 Divergência doutrinária: conceito formal ou material? ............................................ 187

1.2.2 O registro como requisito de admissão à negociação, de lege data ................................. 193

1.2.3 O registro como requisito de admissão à negociação, de lege ferenda ………...............200

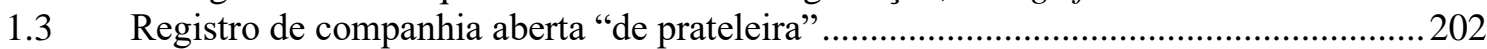

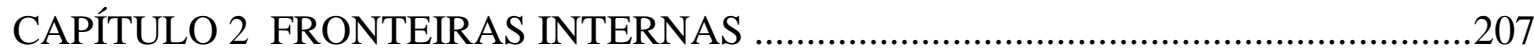

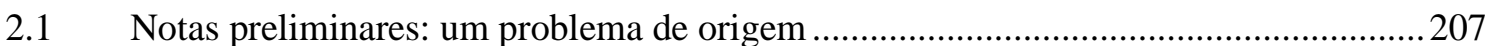

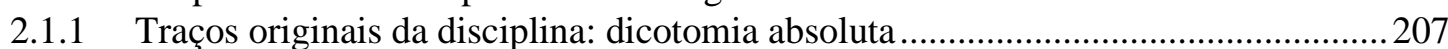

2.1.2 Uma face do problema: espécies de valores mobiliários admitidos à negociação....208

2.1.3 Outra face do problema: diferenças de porte ...........................................................211

2.2 Disciplina da companhia aberta conforme as espécies de valores mobiliários admitidos à

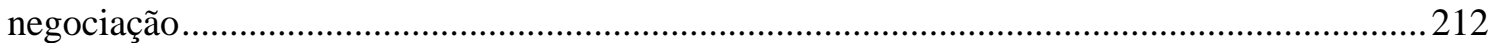

2.2.1 Categorias de registro de companhia aberta (artigo $4^{\circ}, \S^{\circ}$ da Lei n. 6.404/1976)... 212

2.2.2 Regulamentação das categorias de registro (Instrução CVM n. 480/2009)...............221

2.2.2.1 Discussões preliminares (Audiência Pública SDM n. 07/08) ........................................22

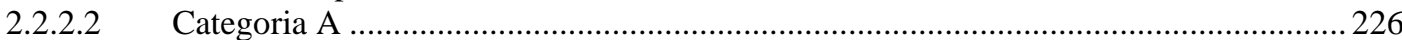

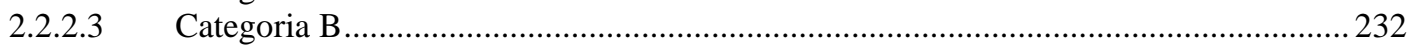

2.2.2.4 Adaptação ao regime de categorias de registro ............................................................22 237

2.2.2.5 Conversão de categoria de registro.............................................................................. 237

2.2.3 Reformas adicionais à disciplina legal da companhia aberta....................................224

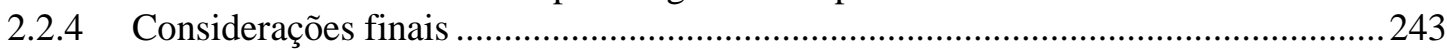

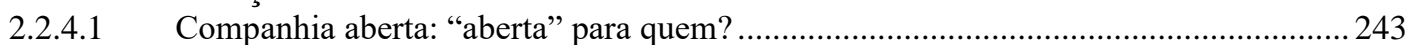

2.2.4.2 Companhias com valores mobiliários de dívida admitidos à negociação........................2245

2.3 Disciplina da companhia aberta conforme o seu porte ...............................................248

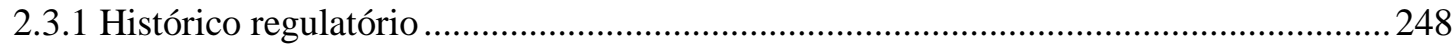

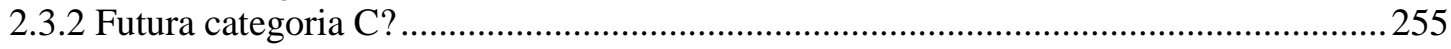

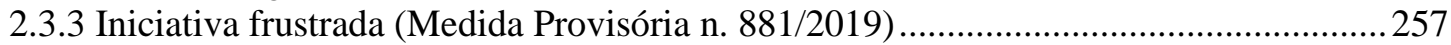

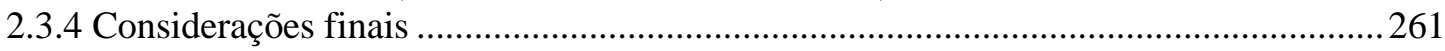

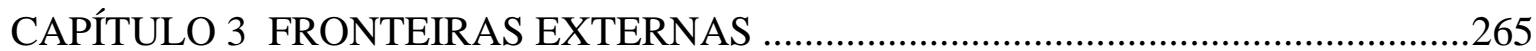

3.1 Notas preliminares: mais uma vez, um problema de origem ……...............................2. 265

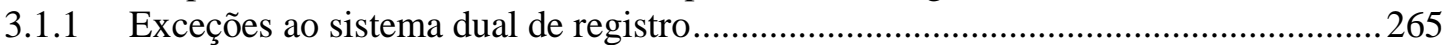

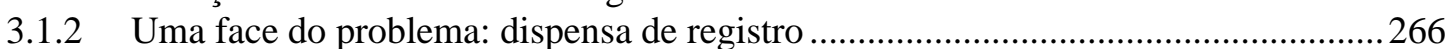

3.1.3 Outra face do problema: registro paralelo ..............................................................2. 268

3.2 Disciplina das companhias que acessam o mercado sob dispensa de registro...............268

3.2.1 Dispensa de registro (artigos $19, \S 5^{\circ}$ e $21, \S 6^{\circ}$ da Lei n. 6.385/1976) .......................268

3.2.2 Regulamentação da dispensa de registro pela CVM..............................................2270

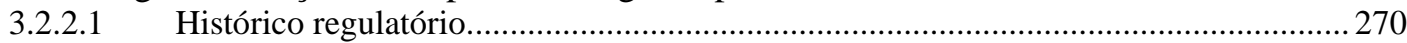

3.2.2.2 Ofertas públicas distribuídas com esforços restritos (Instrução CVM n. 476/2009) .... 275

3.2.2.2.1 Dispensa de registro................................................................................. 275

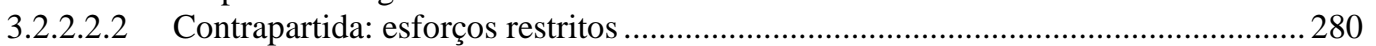

3.2.2.2.3 Distribuição de valores mobiliários de dívida .........................................................228

3.2.2.2.4 Distribuição de valores mobiliários de capital........................................................ 287

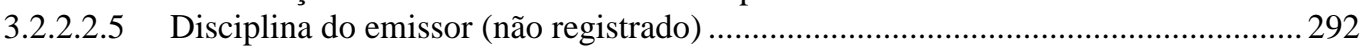

3.2.2.3 Ofertas públicas de crowdfunding de investimento (Instrução CVM n. 588/2017) ..... 295

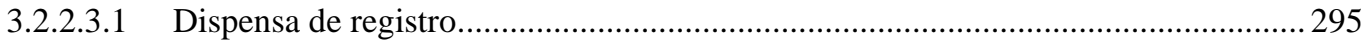

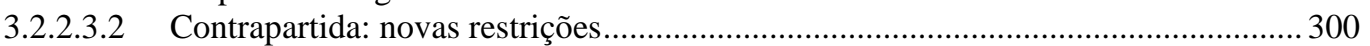

3.2.2.3.3 Disciplina da sociedade empresária de pequeno porte.............................................. 302

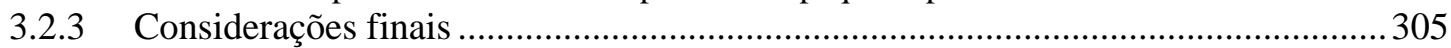

3.2.3.1 Acesso ao mercado por companhia não registrada: antinomia aparente?......................... 305 


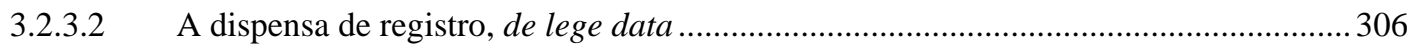

3.2.3.3 A dispensa de registro, de lege ferenda ................................................................... 311

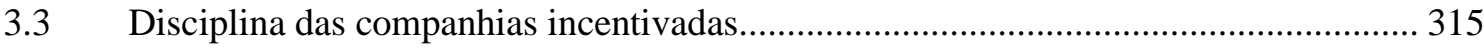

3.3.1 Origem.............................................................................................. 315

3.3.2 Tratamento lateral na reforma de 1976 (artigo 299 da Lei n. 6.404/1976) ............. 317

3.3.3 Disciplina do mercado de títulos e valores mobiliários incentivados (Decreto-lei n.

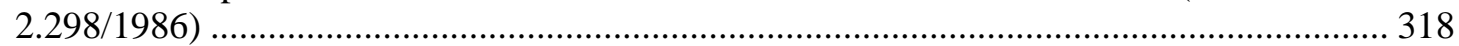

3.3.4 Disciplina das companhias incentivadas (Instrução CVM n. 265/1997)................ 321

3.3.5 Considerações finais ............................................................................. 327

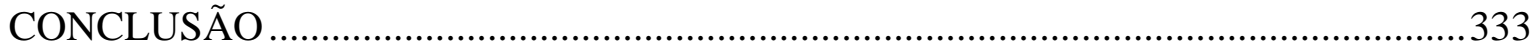

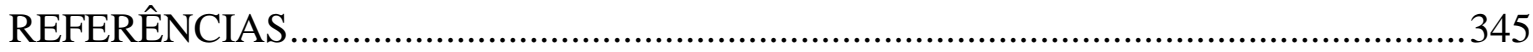





\section{INTRODUÇÃO}

\section{Companhia: aberta?}

O que é a companhia aberta segundo o Direito brasileiro?

Como resposta imediata, dir-se-ia provavelmente que a companhia aberta é aquela cujos valores mobiliários estão admitidos à negociação no mercado de valores mobiliários. Afinal, é essa a definição consagrada há décadas em nossa legislação.

Porém, essa resposta não parece suficiente a fazer cessar a curiosidade.

Ao insistir-se na pergunta, nota-se então que essa definição legal estabelece uma dicotomia entre companhias abertas e fechadas e funciona como ponto terminal de regras ${ }^{1}$, atraindo a incidência de disciplina jurídica própria.

Contudo, daí surgem novas perguntas, de modo que a complexidade da pergunta original começa a se revelar: Que conjunto de regras é esse aplicável às companhias abertas e por quê essas regras incidem a partir da admissão de valores mobiliários de sua emissão à negociação nesse mercado? O que exatamente constitui a admissão à negociação dos valores mobiliários de emissão da companhia? A admissão à negociação, ou a efetiva negociação, de toda e qualquer espécie de valores mobiliários sujeita as companhias emissoras ao mesmo conjunto de regras? E ainda, ficam as companhias abertas sujeitas ao mesmo conjunto de regras independentemente de características como o seu porte, ou da forma e intensidade com que acessam esse mercado? É possível que as companhias acessem o mercado de valores mobiliários sem a atração dessa disciplina?

Por sua vez, essas novas perguntas dão pistas de como o tratamento originalmente conferido às companhias abertas pelo Direito brasileiro foi posto em questão pela realidade subjacente. Apontam, ainda, para a complexidade que o tema foi adquirindo na medida em que, para

\footnotetext{
${ }^{1}$ Adota-se aqui a expressão empregada por Celso Antonio Bandeira de Mello ao tratar do conceito de "serviço público", no sentido de que "toda e qualquer noção jurídica (...) só tem préstimo e utilidade se corresponder a um dado sistema de princípios e regras; isto é, a um regime, uma disciplina peculiar. (...) Eis, pois, que um conceito jurídico é necessariamente um ponto terminal de regras, um termo relacionador de princípios e normas." (cf. BANDEIRA DE MELLO, Celso Antonio. Prestação de serviços públicos e administração indireta. São Paulo: Revista dos Tribunais, 1973. p. 18) Ainda sobre os conceitos jurídicos indeterminados, destacando a definição supracitada: GRAU, Eros Roberto. Os conceitos jurídicos e a doutrina real do Direito. In: Revista da Faculdade de Direito, Universidade de São Paulo, vol. 77, 1982. p. 233.
} 
fazer face à realidade, o universo de normas aplicáveis às companhias abertas foi continuamente alterado e ampliado.

Referimo-nos, em primeiro lugar, às fronteiras internas erigidas dentro dessa disciplina, a partir da adoção de medidas voltadas a tratar diferentemente as diferentes companhias abertas. Destaca-se, nesse sentido, a instituição de diferentes categorias de registro de companhia aberta, cada qual sujeita a subconjuntos específicos de regras.

Em segundo lugar, referimo-nos às medidas adotadas para ampliar o acesso ao mercado de valores mobiliários a outros emissores que se organizem sob a forma de sociedade anônima mas que não possuam registro de companhia aberta, gerando um movimento quase que de erosão das fronteiras externas daquela disciplina. Em especial, ressalta-se a permissão para a realização de ofertas públicas de valores mobiliários sob dispensa de registro.

Não surpreende, portanto, que o quadro atual cause perplexidade e provoque novas indagações quanto a essas fronteiras internas e externas. Afinal, delas decorre uma nova e complexa taxonomia, que, como produto histórico-jurídico, resulta de escolhas feitas com maior ou menor fundamento na realidade ${ }^{2}$. Nessa perspectiva, o termo fronteira é aqui empregado no intuito de situar esses movimentos, destacando os diferentes espaços construídos pelo Direito, dentro ou no entorno desse campo, e assim propondo reflexão sobre o tema a partir da articulação de diferentes linhas divisórias.

Posto que essas inovações foram introduzidas sob a égide de uma disciplina pautada e estruturada em torno da dicotomia entre companhias abertas e fechadas - tanto assim que a definição legal de companhia aberta permanece essencialmente inalterada, do ponto de vista formal -, não é desprezível o esforço de interpretação que por vezes se faz necessário à adequada compreensão e aplicação das normas dessa disciplina.

Soma-se a isso o fato de que a conjugação das novas normas que determinam as fronteiras internas e externas dessa disciplina amplia a gama de possibilidades de acesso ao mercado

\footnotetext{
${ }^{2}$ A reflexão tem inspiração na afirmação de Pierre Bourdieu de que "fronteira nunca é mais do que o produto de uma divisão a que se atribuirá o maior ou menor fundamento na 'realidade' segundo os elementos que ela reúne, tenham entre si semelhanças mais ou menos numerosas e mais ou menos fortes (dando-se por entendido que se pode discutir sempre acerca dos limites de variação entre os elemento não idênticos que a taxinomia trata como semelhantes)." (cf. BOURDIEU, Pierre. O Poder Simbólico. Trad. Fernando Tomaz. 11. ed. Rio de Janeiro: Bertrand Brasil, 2007. p. 114-115) Pontua-se aqui a importância de se enxergar a disciplina jurídica da companhia aberta, como produto histórico-jurídico, sob ótica mais ampla, que permita a compreensão de sua dimensão sociológica. Dentro de suas limitações de escopo e de metodologia, o presente estudo será desenvolvido de maneira atenta às transformações vividas nesse período de transição da sociedade moderna para a contemporânea, buscando compreender e situar as marcas da contemporaneidade que esse exercício revela.
} 
de valores mobiliários pelas companhias no país, revelando uma concorrência entre arranjos jurídicos não necessariamente simétricos.

Os comentários e questionamentos aqui brevemente derivados da pergunta que abre este Capítulo introduzem as principais questões que esta dissertação pretende abordar ao examinar o objeto, a estrutura e as fronteiras da disciplina jurídica da companhia aberta.

\section{Delimitação do tema e sua relevância}

A pergunta inicialmente formulada - "O que é a companhia aberta segundo o Direito brasileiro?" - carrega consigo um importante pressuposto, que delimita os objetivos desta dissertação.

A companhia aberta é elemento da realidade social que poderia ser estudado sob diferentes dimensões, sendo o Direito apenas uma dessas múltiplas facetas. O pressuposto da referida pergunta é exatamente que a companhia aberta existe no Direito brasileiro, como uma construção jurídica por assim dizer, produto do conjunto de normas sobre o tema.

É nesse sentido que esta dissertação se concentra na disciplina jurídica da companhia aberta $^{3}$. Trata-se, essencialmente, de uma tentativa de retratar a companhia aberta em sua dimensão jurídica, que parte da inevitável indagação quanto aos propósitos segundo os quais o Direito se ocupa desse objeto, para então estudar como se desenha sua disciplina normativa 4 .

\footnotetext{
${ }^{3} \mathrm{O}$ termo "disciplina jurídica" é aqui empregado para designar um sistema ou corpo de normas jurídicas destinado a disciplinar, de maneira específica, um dado objeto - no caso desta dissertação, a companhia aberta. Ainda que essa disciplina seja composta por normas de ordens distintas e pertencentes a diferentes diplomas, entendemos que merecem ser estudadas de maneira unitária e sistemática, em vista de seu objeto e objetivos comuns, e por motivo de ordem pragmática - isto é, para permitir a adequada compreensão e análise do tratamento conferido às companhias abertas pelo Direito brasileiro, independentemente e sem que com isso se pretenda adentrar eventual discussão quanto à autonomia dessa disciplina como ramo do Direito.

${ }^{4}$ Dito isso, cumpre ressalvar que a pergunta original ("O que é a companhia aberta segundo o Direito brasileiro?") não é tecnicamente precisa, e foi aqui formulada no intuito exclusivo de elucidar o raciocínio que conduz à delimitação do objeto e dos objetivos desta dissertação. Como bem aponta Alf Ross, perguntas desse tipo ("O que é...?") podem ser adequadas para uma descrição detalhada de um objeto ao qual se refere uma palavra cujo significado está acima de qualquer dúvida ("O que é a água?"), mas não o são quando o que se pretende é precisamente estabelecer o sentido de uma expressão (“O que é o Estado?"). (cf. ROSS, Alf. Sobre los conceptos de "estado" y "órganos del estado" en derecho constitucional. In: El concepto de validez y otros ensayos. Buenos Aires: Centro Editor de America Latina, 1969. p. 85) Não há dúvida de que o objeto desta dissertação pertence ao segundo grupo. Nesse ponto, é pertinente a observação de Eros Grau de que os conceitos jurídicos são usados não para definir essências, e sim para permitir a aplicação de normas jurídicas. (cf. GRAU, Eros Roberto. Os conceitos jurídicos e a doutrina real do Direito. In: Revista da Faculdade de Direito, Universidade de São Paulo, vol. 77, 1982. p. 233)
} 
Notadamente, concentra-se esta dissertação na estrutura normativa inaugurada com o marco legal de 1976. Frutos de um mesmo esforço histórico-político, as Leis n. 6.385/1976 e 6.404/1976 consagraram a já mencionada dicotomia entre companhias abertas e fechadas e lançaram as bases de sua disciplina normativa ${ }^{5}$.

É importante ressaltar que o retrato a que se dedica esta dissertação será traçado com o olhar voltado sobretudo aos contornos da disciplina jurídica da companhia aberta, sem a pretensão de descrever e analisar em destalhes cada uma das normas que a integram. Este estudo mira especialmente certos denominadores comuns dessas normas e o modo como elas se estruturam e se relacionam, donde surgem questões que não se esgotam na análise individualizada e sequencial dessas normas - na verdade, a antecedem.

Nesse desígnio, serão estudadas mais detidamente as fronteiras internas e externas da disciplina jurídica da companhia aberta, exercício esse de particular importância à análise do tema, visto que a taxonomia que dele resulta acusa, a nosso ver, tratamento por vezes assimétrico, ou mesmo assistemático, pelo Direito brasileiro. Desse quadro exsurgem interessantes questões relacionadas à validade das normas que escoram essas fronteiras e à correspondência de normas específicas com os fins que as inspiram ${ }^{6}$, assim como à unidade e coerência interna dessa disciplina ${ }^{7}$.

\footnotetext{
${ }^{5}$ Não obstante, para ilustrar as raízes e relevância da reforma de 1976, os antecedentes normativos da disciplina da companhia aberta serão estudados no Capítulo 2 da Parte I. Ressalva-se que este estudo promove análise parcial da Lei n. 6.404/1976, concentrando-se nas regras dedicadas exclusivamente às companhias abertas, às quais, não obstante, aplica-se também seu regime comum. Não serão examinados os dispositivos daquele diploma dedicados às sociedades em comandita por ações. Também da Lei n. 6.385/1976 este estudo promove análise parcial, concentrando-se nos dispositivos aplicáveis às companhias abertas, sem se aprofundar nas regras que regem os demais participantes e estruturas do mercado de valores mobiliários. Ademais, este estudo se dedica mais às regras que regem o acesso e a permanência das companhias no mercado de valores mobiliários do que naquelas que regem a eventual saída desse mercado. Não integram o escopo de análise normas de natureza fiscal ou outras que incidam em função da configuração como companhia aberta, exceção feita àquelas referidas no Capítulo 2 da Parte I.

${ }^{6} \mathrm{O}$ termo "validade" (ou "vigência") é aqui empregado em referência à existência da norma enquanto tal, o que envolve uma investigação tipicamente jurídica quanto à competência de quem a emanou, se não foi revogada e se não é incompatível com outras regras (isto é, se não houve revogação implícita). (cf. BOBBIO, Norberto. Teoria da Norma Jurídica. $3^{\text {a }}$ ed. Bauru: Edipro, 2005. p. 46-47; REALE, Miguel. Lições preliminares de Direito. $27^{\mathrm{a}}$ ed. São Paulo: Saraiva, 2006. p. 105 et seq.) Já a análise da correspondência entre determinada norma e os fins que a inspiram poderia, no limite, levar a uma investigação tipicamente filosófica em torno da justiça (cf. BOBBIO, Norberto. Teoria da Norma Jurídica. $3^{\text {a }}$ ed. Bauru: Edipro, 2005. p. 51-52), incompatível com a metodologia desta dissertação e com suas limitações de escopo. Portanto, o escopo de análise abrangerá a perquirição das finalidades que inspiram as normas que disciplinam as companhias abertas, preliminar e complementarmente à análise formal dessas normas, evitando discussões de natureza deontológica e restringindo-se à indagação quanto à aptidão de normas específicas à realização de tais fins. Em síntese, não serão objeto de questionamento os fins perseguidos, e sim os instrumentos jurídicos empregados para a consecução de tais fins.

${ }^{7}$ Cf. BOBBIO, Norberto. Teoria de Ordenamento Jurídico. 10ª ed. Brasília: Universidade de Brasília, 1999. p. 34 et seq.
} 
A esta altura é forçoso reconhecer que a companhia aberta não tem mais o mesmo protagonismo que teve à época do marco legal de 1976, dada a posterior ampliação do mercado de valores mobiliários brasileiro a outros emissores, e mesmo o crescimento relativo do mercado de títulos corporativos - aquém do esperado, poder-se-ia dizer, especialmente no tocante ao mercado acionário ${ }^{8}$. Por que, então, dedicar-se a tão delimitado tema?

A redução do protagonismo original da companhia aberta serve de ponto de partida para a resposta a essa indagação. Afinal, como se demonstrará no curso deste trabalho, diversas das questões identificadas a partir do estudo da disciplina jurídica da companhia aberta decorrem de, ou de alguma maneira se relacionam com, os caminhos adotados pelo Direito brasileiro para permitir e incentivar essa ampliação. Ou seja, esse movimento não reduz a importância do objeto de estudo, e sim nele se insere na medida em que contribuiu para moldar as atuais feições dessa disciplina.

Esse retrato da disciplina jurídica da companhia aberta apresenta desafios que lhe são peculiares. Evidentemente, isso não quer dizer que questões semelhantes não se imponham quanto à disciplina jurídica afeta aos demais emissores de valores mobiliários, nem que novas questões não surjam da comparação destas com a disciplina jurídica da companhia aberta. Essas são questões importantes, mas que pertencem a retratos individuais dos diferentes emissores, ou de seu conjunto, enquanto esta dissertação pretende servir tão somente de passo inicial para a construção desse quadro, concentrando o seu campo de visão na companhia aberta.

Com isso, pretende-se fomentar o aprofundamento da análise de questões próprias à disciplina jurídica da companhia aberta, que, apesar de sua relevância prática, permanecem pouco exploradas pela doutrina sob a ótica aqui proposta e merecem ser debatidas e esclarecidas, a bem da adequada compreensão e da reflexão sobre o tema.

Essa abordagem é pautada primordialmente pela preocupação com a promoção de segurança

\footnotetext{
${ }^{8}$ Vide item 3.4 do Capítulo 3 da Parte I. Em paralelo, outros mercados regulados pela CVM - como, por exemplo, os mercados de fundos de investimento e de derivativos - cresceram sobremaneira, tanto em volume quanto em complexidade. Para dados sobre esse crescimento, ver: CVM. Planejamento Estratégico: construindo a CVM de 2023. Versão 2019. Disponível em: http://www.cvm.gov.br/. Acesso em: 08 jul. 2019. Como comenta Trindade, "[o] sentido e o limite das expressões mercado financeiro, mercado de capitais e mercado de valores mobiliários está longe de ser unívoco", sendo que a distinção entre os dois últimos termos "é menos clara na prática" (cf. TRINDADE, Marcelo. Processo sancionador na CVM: limites e possibilidades. In: Lei das S.A. em seus 40 anos. Rio de Janeiro: Forense, 2017. p. 481). Isso posto, serão empregados ambos os termos neste trabalho em referência ao mercado em que são publicamente transacionados os títulos corporativos, o último deles designando mais especificamente o perímetro traçado pela Lei n. 6.385/1976.
} 
jurídica em torno das normas que regem as companhias abertas, de lege data. Bem se sabe que o enquadramento como companhia aberta atrai a incidência de um conjunto específico e mais oneroso de normas; porém, como ilustram as indagações aventadas acima, essa classificação comporta nuances que não se esgotam na simples referência ao critério de distinção binário da definição legal de companhia aberta. Espera-se, portanto, contribuir para a elucidação desse quadro, explorando as aparentes zonas cinzentas quanto à sua delimitação.

A relevância prática do estudo do tema é ilustrada pelos números mais recentes do mercado de valores mobiliários brasileiro, que provocam reflexão sobre a disciplina da companhia aberta e os desafios que a ela se apresentam, com destaque para os seguintes, que serão retomados no curso deste trabalho'

O número de companhias abertas com registro ativo segue em queda, de 647 em 2013 para 607 em novembro de 2019. Em dezembro de 2018, havia apenas 333 companhias abertas com registro ativo e ações negociadas em bolsa de valores;

Além disso, foram poucas, em número e volume, as ofertas públicas iniciais de ações realizadas no Brasil nos últimos anos ${ }^{10}$;

Contudo, no período de 2013 a novembro de 2019, houve um aumento do volume de capitalização de mercado das companhias de $\mathrm{R}$ \$ 2,4 trilhões para $\mathrm{R}$ \$ 4,4 trilhões;

As ofertas públicas com esforços restritos atualmente superam, em quantidade e volume, as ofertas públicas registradas ${ }^{11}$. Mais especificamente, as ofertas públicas com esforços restritos de debêntures superam, em quantidade e volume, as ofertas públicas (registradas e com esforços restritos) de ações ${ }^{12}$;

\footnotetext{
${ }^{9}$ Vide item 3.4 do Capítulo 2 da Parte I. Exceção feita aos dados do último subitem, os demais dados citados a seguir foram extraídos de levantamento divulgado pela própria CVM. (cf. CVM. Boletim de Mercado, ano 7, n. 74, dez. 2019. Disponível em: http://www.cvm.gov.br/publicacao/boletimmercado.html. Acesso em: 02 jan. 2020)

${ }^{10}$ Em 2011, houve 1.717 ofertas públicas iniciais de distribuição de ações, no volume total US\$183,1 bilhões, das quais apenas onze, no volume total de US\$ 4,3 bilhões, ocorreram em bolsa de valores no Brasil. Em 2018 o quadro não foi muito diferente: apenas três ofertas públicas iniciais de distribuição de ações, no volume total US $\$ 2$ bilhões, foram realizadas em bolsa de valores no Brasil, de um total mundial de 1.617 ofertas no volume total de US\$211,3 bilhões.

${ }^{11}$ Em 2018, houve 76 ofertas registradas sob a Instrução CVM n. 400/2003 e 991 ofertas com esforços restritos sob a Instrução CVM n. 476/2009, somando, respectivamente, R \$ 33,5 bilhões e R \$ 243,6 bilhões. Em 2019, até o mês de novembro houve 108 ofertas registradas sob a Instrução CVM n. 400/2003 e 964 ofertas com esforços restritos sob a Instrução CVM n. 476/2009, somando, respectivamente, R \$ 82,4 bilhões e R\$ 309,5 bilhões.

${ }^{12}$ Em 2018, houve cinco ofertas registradas e 346 ofertas com esforços restritos de debêntures, somando, respectivamente, $\mathrm{R}$ \$ 2,7 bilhões e $\mathrm{R} \$ 146,4$ bilhões. No mesmo período, houve apenas três ofertas registradas e duas ofertas com esforços restritos de ações, somando, respectivamente, $\mathrm{R}$ \$ 4,4 bilhões e R 6,8 bilhões. Em
} 
Do total de ofertas públicas com esforços restritos de debêntures realizadas nos últimos anos, boa parte teve por emissores companhias de capital fechado ${ }^{13}$.

Em vista desse quadro, não surpreende que estejam na ordem do dia discussões diversas em torno de medidas voltadas a promover o desenvolvimento desse mercado e a diminuição do custo regulatório de seus participantes ${ }^{14}$, que poderão brevemente se materializar por reformas em sede regulamentar ${ }^{15}$. Soma-se o fato de medidas correlatas terem sido propostas por meios outros, como Medidas Provisórias, no ano de $2019^{16}$.

Nos parece oportuno o debate sobre tais medidas e acertada a preocupação com o tema. Espera-se assim contribuir para a promoção de reflexão em torno dos contornos da disciplina jurídica da companhia aberta, inclusive quanto aos novos caminhos que a ela se apresentam, de lege ferenda.

2019, até o mês de novembro houve oito ofertas registradas e 301 ofertas com esforços restritos de debêntures, somando, respectivamente, $\mathrm{R} \$ 12,1$ bilhões e $\mathrm{R} \$ 150,3$ bilhões. No mesmo período, houve dez ofertas registradas e 25 ofertas com esforços restritos de ações, somando, respectivamente, $R \$ 35,2$ bilhões e $R \$ 42,5$ bilhões.

${ }^{13} \mathrm{O}$ levantamento é feito pela ANBIMA a partir de distinção entre "empresas de capital aberto" e "empresas de capital fechado". Em 2013, as ofertas lançadas por "empresas de capital fechado" representaram 50,8\% do volume total e $67,9 \%$ do número total de ofertas públicas com esforços restritos de debêntures daquele ano. Em 2018, as ofertas públicas com esforços restritos de debêntures lançadas por "empresas de capital fechado" representaram 53,3\% do volume total e 62,7\% do número total de operações daquele ano. Em 2019, as ofertas públicas com esforços restritos de debêntures lançadas por "empresas de capital fechado" representaram 32,3\% do volume total e $60,1 \%$ do número total de operações daquele ano. (cf. ANBIMA. Boletim de Mercado de Capitais, dezembro/2019. Disponível em: https://www.anbima.com.br/pt_br/informar/relatorios/mercado-decapitais/boletim-de-mercado-de-capitais/emissoes-domesticas-registram-aumento-de-59-3-em-2019.htm.

Acesso em: 08 jan. 2020)

${ }^{14}$ Por exemplo: em novembro de 2017, a CVM deu início ao "Projeto Estratégico de Redução de Custo de Observância Regulatória”. Sobre o tema, confira-se: CVM. Custo de observância regulatória. http://www.cvm.gov.br/legislacao/custo_observancia.html. Acesso em: 25 mar. 2019; BARBOSA, Marcelo. PEREIRA, Catarina. Custos de observância e o equilíbrio regulatório: a CVM e os bastidores do projeto de redução do custo de observância. 2018. Disponível em: https://www.jota.info/tributos-eempresas/mercado/custos-de-observancia-e-o-equilibrio-regulatorio-19122018. Acesso em: 25 mar. 2019; CVM. Deliberação CVM 809 traz inovações relacionadas ao registro de ofertas públicas: medidas fazem parte do projeto de redução dos custos de observância e estão em linha com as práticas internacionais. 2019. Disponível em: http://www.cvm.gov.br/noticias/arquivos/2019/20190219-2.html. Acesso em: 25 mar. 2019.

${ }^{15}$ Como detalhado no Capítulo 2 da Parte II, em 4 de fevereiro de 2019, a CVM divulgou lista de prioridades de sua agenda regulatória para aquele ano, que incluiu a revisão do regime informacional das companhias. Diz a nota que durante o ano de 2019 a CVM pretendia realizar estudo normativo com o objetivo de tornar mais simples e objetivo o formulário de referência de que trata a Instrução CVM n. 480/2009, bem como que essa iniciativa surgiu a partir de contribuições do "Projeto Estratégico Custo de Observância". Além disso, diz a nota que nesse âmbito será também "avaliada a criação de nova categoria de companhias, a princípio denominada " $C$ " (hoje existem a " $A$ " $e$ " $B$ "), para abarcar companhias de menor porte, com regulamentação diferenciada, de forma a estimular e promover a entrada de mais empresas no mercado". (cf. CVM. Agenda Regulatória CVM 2019. Disponível em: http://www.cvm.gov.br/noticias/arquivos/2019/20190204-1.html. Acesso em: 21 mar. 2019) A revisão do regime informacional das companhias agora consta da agenda regulatória da CVM para o ano de 2020, sob a indicação de "tema para audiência pública", junto com a revisão do arcabouço de ofertas públicas. (cf. CVM. Regime informacional e ofertas públicas estão na agenda regulatória CVM 2020. Disponível em: http://www.cvm.gov.br/noticias/index.html. Acesso em 08 jan. 2020)

${ }^{16}$ Vide Capítulo 2 da Parte II. 
Uma nota final se faz necessária para ressalvar que não se está aqui a propor uma ampla revisão da disciplina legal da companhia aberta - ao contrário, tem-se em vista a inegável qualidade e plasticidade dos referidos diplomas -, e quanto menos o redirecionamento da agenda regulatória. Não obstante, se da análise das questões teóricas a que esta dissertação se dedica despontam considerações de ordem prática, é tão somente no intuito de contribuir para esse debate circunscrito, sujeito às referidas limitações.

\section{Plano de trabalho e metodologia}

Esta dissertação é dividida em duas partes, cada qual composta por três capítulos, além desta Introdução e da Conclusão.

A Parte I será dedicada à identificação do objeto e à análise da estrutura da disciplina jurídica da companhia aberta, no intuito de proporcionar uma visão panorâmica do tema.

No Capítulo 1 analisar-se-á de maneira introdutória a relação entre a companhia aberta e o Direito, com foco nas origens históricas e elementos fundamentais dessa tutela em diferentes países, o que servirá de base referencial para a contextualização e construção do estudo da disciplina da companhia aberta pelo Direito brasileiro.

No Capítulo 2 dar-se-á início ao estudo da disciplina da companhia aberta pelo Direito brasileiro, com o exame de seus antecedentes normativos, com vistas a contribuir à compreensão das raízes e da relevância da reforma promovida em 1976.

No Capítulo 3 dar-se-á continuidade ao estudo da disciplina da companhia aberta pelo Direito brasileiro tal como consagrada a partir do marco legal de 1976, investigando o contexto e os objetivos dessa reforma. Essa análise será concentrada no plano das Leis n. 6.385/1976 e 6.404/1976 e obedecerá a ordem cronológica, no intuito de explorar como foi originalmente delineado o objeto e estruturada essa disciplina, bem como o impacto para esses fins das principais reformas e alterações posteriormente introduzidas.

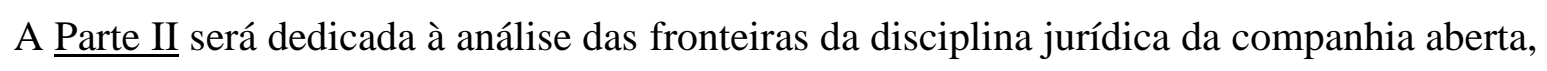
com foco nas normas legais e regulamentares que moldam essas fronteiras, tomando por base o estudo sobre o objeto e a estrutura da disciplina na Parte I.

No Capítulo 1 examinar-se-á a relação entre as normas sobre o registro de emissor e o registro de oferta pública de distribuição de valores mobiliários e as referidas fronteiras, com 
foco nos elementos fundamentais de definição do objeto e de atração dessa disciplina.

No Capítulo 2 serão exploradas as fronteiras internas da disciplina jurídica da companhia aberta, com foco nas principais iniciativas no tocante à disciplina das companhias abertas conforme a espécie de valores mobiliários de sua emissão admitidos à negociação - em especial, as categorias de registro de companhia aberta - e conforme o seu porte.

No Capítulo 3 serão analisadas as fronteiras externas da disciplina jurídica da companhia aberta, com destaque para as principais iniciativas no tocante à dispensa dos registros antes mencionados e à administração do registro paralelo para as companhias incentivadas.

Finalmente, na Conclusão, as conclusões parciais dos capítulos anteriores serão consolidadas e articuladas, com vistas a oferecer um retrato da companhia aberta em sua dimensão jurídica, construído a partir do exame do objeto e da estrutura dessa disciplina.

A disciplina jurídica da companhia aberta será aqui considerada não apenas sob o prisma formal, mas como produto de situações histórico-políticas. A perspectiva histórica será priorizada especialmente nas abordagens de pesquisa e interpretação, buscando-se um estudo não estático, e sim iluminado pela evolução dessa disciplina e da realidade subjacente. Para tanto, as normas pertinentes serão encaradas sob dupla visão, retrospectiva e prospectiva ${ }^{17}$.

O principal substrato para esse estudo será a produção normativa em torno do tema, isto é, as normas em vigor e aquelas já revogadas pertinentes às companhias abertas no Brasil ${ }^{18}$. Contudo, como bem assinala Bobbio, "[o] legislador é um personagem imaginário que esconde uma realidade mais complicada" ${ }^{\prime 19}$. Para descortinar essa realidade, recorrer-se-á a

\footnotetext{
${ }^{17}$ Refere-se aqui à lição de Reale acerca da teoria da interpretação histórico-evolutiva da norma jurídica, que tem por corolário a concepção de que esta se desprende da pessoa do legislador (como a criança se livra do ventre materno, como disse Saleilles) e tem vida própria, podendo assim adquirir novos significados conforme a transformação da realidade subjacente. (cf. REALE, Miguel. Lições preliminares de Direito. $27^{\mathrm{a}}$ ed. São Paulo: Saraiva, 2006. p. 293-294)

${ }^{18}$ Ainda dentro dessa perspectiva, o Direito estrangeiro será tido em conta como subsídio de análise na medida em que isso se justificar por sua contribuição para a compreensão das origens e a reflexão sobre os contornos da disciplina brasileira, e sem que com isso se pretenda desenvolver uma análise propriamente de Direito comparado sobre o tema. Nesse ponto, invoca-se a lição de Ascarelli a respeito da importância do estudo do Direito estrangeiro à identificação de premissas implícitas de nosso Direito: "Estudando o Direito estrangeiro e descobrindo-lhe as premissas, eventualmente diferentes das do seu direito nacional, ocorrer-lhe-á, às vêzes, encontrar, ao cabo do estudo de um direito estrangeiro, uma explicação melhor para alguns problemas do direito do seu país." (cf. ASCARELLI, Tullio. Problemas das sociedades anônimas e Direito comparado. $2^{\mathrm{a}}$ ed. São Paulo: Saraiva, 1969. p. 10) Como comenta Comparato, "[o] conhecimento desses pressupostos, no entanto, é indispensável aos intérpretes do sistema jurídico, sobretudo diante de institutos de importação." (cf. COMPARATO, Fábio Konder. Novos Ensaios e Pareceres de Direito Empresarial. Rio de Janeiro: Forense, 1981. p. 3)

${ }^{19}$ Cf. BOBBIO, Norberto. Teoria de Ordenamento Jurídico. 10ª ed. Brasília: Universidade de Brasília, 1999. p. 37 .
} 
fontes secundárias como exposições de motivos, relatórios de audiência pública e outras pertinentes ao processo de produção normativa, como registros históricos das motivações para edição, alteração ou revogação de diferentes normas e do sentido que se lhes pretendeu conferir. Também as abordagens do tema em sede doutrinária e jurisprudencial - em especial, na jurisprudência administrativa da CVM - serão levadas em consideração enquanto fotografias de convicções e expectativas contemporâneas.

Por fim, dados estatísticos e outras informações disponíveis, relacionadas à realidade das companhias abertas e do mercado de valores mobiliários brasileiro, serão levados em consideração como retratos da realidade subjacente à aludida disciplina jurídica, sem que com isso se pretenda desenvolver um estudo histórico-econômico sobre o tema ${ }^{20}$.

\footnotetext{
${ }^{20}$ Nesse ponto, apesar de abalizadas as fontes, faz-se necessária a ressalva quanto à dificuldade de verificação da metodologia empregada e dos critérios adotados no cômputo de dados sobre as companhias abertas e o mercado de valores mobiliários.
} 


\section{CONCLUSÃO}

Iniciamos esta dissertação enunciando o objetivo de retratar a companhia aberta em sua dimensão jurídica, partindo da indagação quanto aos propósitos segundo os quais o Direito se ocupa desse objeto, para então estudar como se desenha sua disciplina normativa.

No Capítulo 1 da Parte I apontamos os elementos fundamentais do tipo societário de sociedade anônima, que, como diziam Lamy e Bulhões, "têm origem e fundamento em sua função no mercado de capitais" ${ }^{897}$. Comentamos a crescente utilização desse tipo societário por companhias menores, muitas vezes sem a pretensão de acesso ao mercado de capitais. E ainda, a paulatina incorporação da distinção entre companhias "abertas" e "fechadas" à legislação de diferentes países, face às características que as distinguem, para a concessão de tutela específica.

Nesse contexto, identificamos certos denominadores comuns da conceituação de companhia "aberta" e seus reflexos sob a ótica da legislação societária e do mercado de capitais, bem como algumas tendências mais recentes no tocante à sua disciplina no plano internacional, com destaque para a crítica à influência no direito societário de uma concepção da grande companhia "aberta” distante da realidade presente em alguns países.

No Capítulo 2 da Parte I, o estudo realizado quanto aos antecedentes normativos da disciplina introduzida no Brasil em 1976, permite compreender doravante a relevância e o caráter inovador dessa reforma, especialmente na esfera societária. Isso porque o regime anterior, do Decreto-lei n. 2.627/1940, se pautava na visão abstrata de uma configuração média de sociedade anônima, conferindo tratamento uniforme que recebeu severas críticas. Já a Lei n. 4.728/1965, ao disciplinar o mercado de capitais e exigir o registro das pessoas jurídicas de direito privado como condição à negociação em bolsa de títulos e valores mobiliários, instituiu distinção embrionária da futura classificação das companhias como abertas ou fechadas. Com efeito, a definição de companhia aberta foi formulada de maneira a se ajustar à disciplina da Lei n. 4.728/1965, como aponta a respectiva Exposição de Motivos $^{898}$.

Também importante para a adequada compreensão do contexto e das influências da reforma de 1976 foi o exame, empreendido no Capítulo 2 da Parte I, da classificação de sociedade

${ }^{897}$ Cf. LAMY FILHO, Alfredo. BULHÕES PEDREIRA, José Luiz. Direito das companhias. $2^{\mathrm{a}}$ ed. Rio de Janeiro: Forense, 2017. p. 95.

${ }^{898}$ Cf. Exposição de Motivos n. 196/1976. 
anônima de capital aberto, instituída para fins fiscais. Estipulada no curso de um projeto de promoção do desenvolvimento do mercado de capitais por meio do incentivo (fiscal) à abertura e à democratização do capital das companhias, essa classificação contribuiu para a difusão da percepção em torno da distinção entre companhias que costumavam ou não acessar o mercado, com maior ou menor dispersão acionária, e sua posterior consagração em lei. Relatos sobre dificuldades enfrentadas na tentativa de estabelecer critérios de classificação modulados conforme a realidade subjacente, e condizentes com o mencionado projeto político, iluminam o contraste com a opção do legislador de 1976 pelo emprego de critério único de classificação ao definir-se a "companhia aberta". E ainda, reforçam a importância de atentar-se para a distinção entre uma e outra, a despeito de sua posterior consolidação. Com efeito, o conceito de companhia aberta foi formulado de maneira propositalmente mais ampla que o conceito fiscal de sociedade anônima de capital aberto.

No Capítulo 3 da Parte I, examinamos a estrutura da disciplina societária inaugurada pela Lei n. 6.404/1976, calcada na dicotomia então instaurada entre companhias abertas e fechadas, direcionando-se tutela específica a cada qual. Analisamos também a disciplina dedicada às companhias abertas no âmbito da Lei n. 6.385/1976, enquanto emissoras de valores mobiliários. O estudo mostra que a definição de companhia aberta constrói uma ponte entre os dois diplomas, em ambos tendo sido empregada para o fim instrumental de apontar as regras a ela destinadas dentro desse novo sistema.

A investigação inicial quanto ao contexto da reforma de 1976 e os estudos que a precederam revelaram grande influência, na época, dos objetivos políticos de promoção do desenvolvimento da grande empresa nacional de capital privado e do mercado primário de ações. Pretendia-se, como diz a Exposição de Motivos da lei societária, "criar a estrutura jurídica necessária ao fortalecimento do mercado de capitais de risco no País, imprescindivel à sobrevivência da empresa privada na fase atual da economia brasileira" 899 .

Também essencial para a adequada compreensão do tema é o exame dos objetivos básicos que informam a disciplina legal da companhia aberta, de estímulo à formação e à alocação da poupança popular no mercado de valores mobiliários, e de sua proteção. O complexo e sensível equilibro entre esses objetivos, que as Leis n. 6.385/1976 e 6.404/1976 tentam conjugar, e que reformas e alterações posteriores vieram a modular, oscilando entre medidas

${ }^{899}$ Cf. Exposição de Motivos n. 196/1976. 
de estímulo e de proteção, de flexibilização e de restrição, são elementos fundamentais de sua história. São esses os objetivos que permitem a compreensão sistêmica e finalística dessas leis, e a avaliação da adequação de normas específicas, como abordado em algumas passagens deste trabalho ${ }^{900}$.

Notadamente, a definição de companhia aberta consagrada nas Leis n. 6.385/1976 e 6.404/1976 não pode ser adequadamente compreendida senão como instrumento desse regime de proteção. Tal definição não faz distinção quanto aos valores mobiliários admitidos à negociação, nem quanto a características das companhias como seu porte ou nível de dispersão acionária, ou ainda quanto ao mercado (de bolsa ou balcão, organizado ou não) em que forem admitidos à negociação. Foram enquadradas como companhias abertas simplesmente aquelas “cujos valores mobiliários estejam admitidos à negociação na bolsa ou no mercado de balcão" 901 . Ao traçar o campo mais abrangente, sobressai a preocupação do legislador com a adequada tutela dos potenciais investidores.

Quanto à Lei n. 6.404/1976, vimos que a disciplina especial da companhia aberta, tal como originalmente delineada, era largamente homogênea e incluiu exigências diversas de natureza societária. Porém, algumas dessas exigências, não obstante a abrangente definição legal de companhia aberta, pareciam voltar-se sobretudo ao ideal da grande empresa de capital privado.

Como ressaltado na Introdução, essa disciplina foi abordada sem a pretensão de descrever e analisar cada uma das normas que a integram, e sim com atenção voltada à compreensão de como se estruturam e se relacionam, donde surgem questões que não se esgotam na análise individualizada e sequencial dessas normas - na verdade, a antecedem.

Tal estudo expôs a dimensão atrelada ao status de companhia aberta sob a Lei n. 6.385/1976, especialmente no tocante ao alcance da esfera de responsabilidade administrativa, abrangendo inclusive a matéria societária. Desse estudo despontou o contraste entre as diferentes características e sistemáticas dos diplomas em questão, sendo a Lei n. 6.385/1976 ainda mais centrada na delegação de poderes à CVM para regulamentar as matérias por ele abrangidas, tal como o sistema de registros que governa o acesso ao mercado de valores

\footnotetext{
900 Apoia-se aqui na lição de Reale, comentando os ensinamentos de Jhering, a respeito da importância de se compreender a lei na plenitude de seus fins sociais, possibilitando que se penetre na estrutura de suas significações particulares. Como afirma Reale, "[o] que se quer atingir é uma correlação coerente entre "o todo da lei" e as "partes " representadas por seus artigos e preceitos, à luz dos objetivos visados." (cf. REALE, Miguel. Lições preliminares de Direito. 27ª ed. São Paulo: Saraiva, 2006. p. 289 et seq.)

${ }^{901}$ Cf. artigo 22, caput, da Lei n. 6.385/1976.
} 
mobiliários e o regime informacional obrigatório imposto como condição à manutenção desse registro. Também evidenciou a redução do protagonismo da companhia aberta no âmbito da Lei n. 6.385/1976, como reflexo da ampliação do conceito de valor mobiliário e a extensão de sua disciplina a outros emissores, seus administradores e controladores.

A análise de escopo mais restrito da Parte II deste trabalho confirmou o que já indicava o estudo mais panorâmico do Capítulo 3 da Parte I, isto é, que as reformas e alterações introduzidas às Leis n. 6.385/1976 e 6.404/1976, em especial aquelas de 1997 e de 2001, não guardaram inteira coerência com o objeto e a estrutura original dos diplomas. Diz-se isso mais em tom de constatação do que de crítica. Afinal, diversas das alterações posteriormente introduzidas tiveram a importante função de promover certa flexibilização, em pontos em que se entendeu excessiva a proteção anteriormente dispensada. Nesse sentido, destaca-se a estipulação de regras direcionadas a universos distintos de companhias, como aquelas “cujas ações não estejam admitidas à negociação em bolsa ou no mercado de balcão" ${ }^{902}$, afastando-se assim da antiga dicotomia. Entretanto, outras mudanças foram ali criticadas, por terem sido inseridas em um e não em outro diploma, comprometendo a divisão originalmente pretendida - tal como as regras sobre o cancelamento e as categorias de registro, inseridas na lei societária.

No Capítulo 1 da Parte II, examinamos o sistema dual de registro e sua importância - em especial, do registro de emissor - para a determinação do campo de incidência da disciplina legal da companhia aberta. Salientamos a divergência em torno dos critérios determinantes para o enquadramento sob a definição legal de companhia aberta, notadamente se se trata de conceito formal ou material, para então concluir que a interpretação que melhor se coaduna com a sistemática interna e integrada daqueles diplomas é a que entende a admissão à negociação de valores mobiliários de emissão da companhia como critério formal, sinônimo de registro.

Essa percepção ilumina a destacada função atrelada ao registro, não apenas de instrumento da tutela da informação, mas também como marco para a incidência de disciplina especial, de natureza societária, e a ampliação da esfera de responsabilidade, de lege data. E ainda, incita reflexão em torno da adequação desse sistema de registros, sob a ótica das finalidades almejadas pela disciplina legal da companhia aberta, de lege ferenda. Isso não apenas em função das divergências em torno dos efeitos do registro e de sua dispensa, examinadas ao

902 Cf. artigo 136, caput, da Lei n. 6.404/1976 (que, antes da reforma de 1997, referia-se à "companhia fechada"). 
decorrer deste trabalho, que comprometem a promoção de segurança jurídica, mas, principalmente, ante a aparente contradição que o quadro resultante da articulação das normas sobre registro revela, em que diversas companhias registradas - que, contudo, não acessam o mercado de valores mobiliários (i.e., companhias abertas "de prateleira") - são submetidas à correspondente disciplina, ao passo que diversas outras não registradas - que acessam esse mercado sob dispensa de registro - não o são.

Ressalva-se que não se está a defender a migração para regime centrado em um conceito material, que pressuponha a efetiva negociação dos valores mobiliários de emissão da companhia aberta, ou mesmo que o cerne do problema esteja na opção por critério formal. A proposta é de tão somente expor a complexidade do contraste entre a forma como essa disciplina foi originalmente estruturada, a partir da antiga dicotomia entre companhias abertas e fechadas, registradas ou não, que formalmente sobrevive na definição legal de companhia aberta, e como tal disciplina subsequentemente se transformou. A rigidez da estrutura original - especialmente no âmbito da lei societária, que importa a mecânica do registro da lei do mercado de valores mobiliários - deixava reduzida margem para flexibilização.

Todavia, pelos motivos expostos neste trabalho, parece importante que haja válvulas que permitam a adaptação desse regime conforme os destinatários dessa tutela e sua flexibilização quando a proteção garantida não se mostrar necessária, conquanto certas soluções adotadas nesse intuito, especialmente no âmbito da lei societária, não tenham sido suficientes, ou adequadas, conforme apontado, para a consecução dessa finalidade.

Notadamente, no Capítulo 2 da Parte II, examinamos diferentes iniciativas voltadas a permitir a adequação da disciplina legal e regulamentar da companhia aberta, em torno de dois critérios. Primeiramente, tratamos das medidas adotadas para moldar essa disciplina conforme as espécies de valores mobiliários admitidos à negociação, tomando por base a distinção geral entre valores mobiliários de capital e valores mobiliários de dívida. Esse estudo apontou tendência no sentido de maior delimitação do universo de destinatários de diferentes exigências dessa disciplina. Porém, decorre principalmente de alterações pontuais, esparsas, e não de uma revisão estrutural da disciplina legal da companhia aberta sob essa ótica. Talvez por isso não seja intuitiva a compreensão de que não há na lei um único conjunto de regras que incide ou não conforme a companhia seja aberta ou fechada, e sim regras que se aplicam a todas as companhias abertas, outras regras que se cingem àquelas com ações admitidas à negociação, outras ainda que se dirigem apenas àquelas "abertas 
exclusivamente para a captação de recursos por debêntures não conversíveis em ações", e outras mais, nessa trilha.

Nessa conjuntura, analisamos a autorização inserida em lei para a criação de diferentes categorias de companhia aberta "segundo as espécies e classes dos valores mobiliários por ela emitidos negociados no mercado", e sua regulamentação pela CVM. Exsurge desse exame o contraste entre a limitação de alcance a que essa iniciativa ficou sujeita, de um lado, e, de outro, o objetivo de maior flexibilização da disciplina legal e regulamentar que parece ter pautado sua adoção. Apesar de louvável a inciativa, tal como instituídas, as categorias de registro tiveram repercussão limitada, e não nos parecem suficientes a remediar o problema decorrente da rigidez estrutural da disciplina legal da companhia aberta sob a Lei n. 6.404/1976, constatada nos Capítulos anteriores. Por outro lado, assinala um afastamento para alguns, um verdadeiro rompimento - com relação à antiga dicotomia entre companhias abertas e fechadas, e dá feição nova a essa disciplina. Mais ainda, dela nascem novos desafios que merecem atenção, como é o caso da conversão de registro e da situação de companhias que para esse fim promovem oferta pública de cancelamento do registro para negociação de ações.

Repisamos a observação enfatizada na Introdução quanto ao foco dedicado por este trabalho a questões que antecedem a análise individualizada das normas da disciplina da companhia aberta, tal como o confronto entre o alcance dessas normas e seus pressupostos teóricos. O exame formulado pretende destacar a importância desse alinhamento e os riscos à consecução dos objetivos dessa disciplina de se impor medidas de proteção potencialmente inadequadas ou excessivamente onerosas. O ponto é ilustrado por provocações como: faz sentido impor às companhias abertas exclusivamente para a captação de recursos por debêntures não conversíveis em ações as exigências, por exemplo, dos artigos 254-A e 256 da lei societária?

Também no Capítulo 2 da Parte II abordamos certas iniciativas voltadas à adequação desse regime conforme o porte das companhias, o que remete à antiga e relevante preocupação com a onerosidade de se submeter todas as companhias a regime comum, dificultando o acesso de companhias de menor porte a esse mercado. Essa mesma preocupação informa as principais medidas examinadas no Capítulo 3 da Parte II. Todavia, iniciamos o exame da matéria no Capítulo 2 em razão da iniciativa implementada por meio da Medida Provisória n. 881/2019 - que, contudo, foi depois deixada de fora do respectivo projeto de lei de conversão - que incluíra autorização na lei societária para a CVM “dispensar exigências 
previstas nesta Lei, para companhias que definir como de pequeno e médio porte, de forma a facilitar o acesso ao mercado de capitais" (artigo 294-A), bem como em atenção à intenção anunciada pela CVM de potencialmente criar uma terceira categoria de registro para abarcar companhias de menor porte ${ }^{903}$.

Com isso, buscou-se explorar os pontos de conexão entre a iniciativa de disciplina segundo o porte e aquela de instituição de categorias de registro de companhia aberta conforme as espécies de valores mobiliários admitidos à negociação, bem como propor reflexão em torno da forma como tais flexibilizações foram cogitadas e a sensível mudança que poderiam representar para o regime da lei societária. Entretanto, diante do encerramento da vigência da referida Medida Provisória, retornamos ao quadro anterior, em que a rigidez estrutural da disciplina da companhia aberta parece impulsionar o recurso por companhias de menor porte a situações alternativas à do registro, como aquelas examinadas no Capítulo 3 da Parte II.

Em especial, referimo-nos às hipóteses de dispensa automática de registro estipuladas pela CVM com base na autorização concedida pela Lei n. 6.385/1976, como no caso das ofertas públicas distribuídas com esforços restritos e das ofertas públicas de crowdfunding de investimento, examinadas no Capítulo 3 da Parte II. Iniciativas como essas permitiram a ampliação do acesso ao mercado de valores mobiliários, à margem da disciplina legal da companhia aberta, novamente distanciando-se da concepção que pautava a antiga dicotomia, qual seja, que a oferta pública de distribuição de valores mobiliários e sua negociação em mercado secundário eram privativas das companhias abertas. Vimos que o mecanismo de dispensa de registro consagrou-se como importante instrumento de política regulatória, cuja popularidade é evidenciada pelas estatísticas mais recentes desse mercado, apontadas no Capítulo 3 da Parte I. Enfrentamos a divergência em torno dos efeitos da dispensa de registro vis-à-vis a definição legal de companhia aberta, concluindo que a interpretação que melhor se coaduna com a sistemática dos diplomas legais e com as finalidades que pautam essa tutela é a de que o acesso ao mercado sob dispensa de registro não produz o enquadramento como companhia aberta e não submete os emissores não registrados à correspondente disciplina, de lege data ${ }^{904}$.

\footnotetext{
903 Cf. CVM. Agenda Regulatória CVM 2019. Disponível em: http://www.cvm.gov.br/noticias/arquivos/2019/20190204-1.html. Acesso em: 21 mar. 2019.

${ }^{904}$ Registre-se, no tocante a essa divergência que, caso a conclusão fosse a contrária, estar-se-ia diante de quadro antes mais grave de restrição. É esta a posição de Pitta, que, em função disso, reclama que "existem importantes restrições decorrentes da própria legislação que dificultam a delimitação de um perímetro regulatório sob o qual possa ser desenvolvido um mercado secundário alternativo em que a negociação, ainda
} 
Não obstante, a relevante concentração, quanto a volume de captação, em mecanismos de dispensa de registro - em especial, ofertas públicas distribuídas com esforços restritos - e sua utilização por emissores não registrados desperta reflexão sobre esse instituto, de lege ferenda. Isso não apenas em função da insegurança que a dificuldade de interpretação e a falta de consenso em torno de seus efeitos produz, mas também, e especialmente, do contraste com o seu caráter de exceção à regra geral da obrigatoriedade de registro. Em outras palavras, nos parece importante que o registro possa ser dispensado e que com isso a disciplina legal da companhia aberta possa ser excepcionada quando o interesse público assim o justificar ${ }^{905}$. Contudo, os números parecem contradizer a ideia de que a dispensa de registro constitui regime especial, de exceção, em relação à regra geral da obrigatoriedade de registro. Isso pode decorrer, ou se relacionar, com uma série de fatores, desde a rigidez estrutural da disciplina da companhia aberta até a falta de adequada definição em torno do conceito de oferta pública, além de outros fatores não exclusivamente jurídicos. De todo modo, essa tendência parece apontar para um movimento de certa erosão do campo de abrangência da disciplina da companhia aberta, e sugerir a conveniência de potencial migração para um regime menos concentrado em modelos e conceitos ("companhia aberta" e "oferta pública") que deem margem a dúvidas desse tipo.

Por último, examinamos o sistema paralelo de registro instituído para as chamadas companhias incentivadas, como dado histórico de iniciativa voltada a permitir a ampliação do acesso ao mercado de valores mobiliários - nesse caso, de maneira bastante particular também à margem da disciplina legal da companhia aberta, no intuito declarado de evitar "que aquelas companhias tenham que, de imediato, arcar com todas as obrigações legais próprias às companhias abertas" $" 906$. Em comum com as hipóteses de dispensa automática de registro, houve também nesse caso o objetivo de estabelecer regime mais flexível e proporcional à realidade subjacente. Ao mesmo tempo, a forma como isso foi feito parece prejudicar a sistematicidade, especialmente da Lei n. 6.385/1976, e dificultar a compreensão global da matéria.

\footnotetext{
que restrita, de valores mobiliários ocorra sem que implique na aquisição do status de companhia aberta por parte de seus emissores". (cf. PITTA, André Grünspun. A capitalização da empresa e o mercado de valores mobiliários. São Paulo: Quartier Latin, 2018. p. 411)

905 Reitera-se aqui a lição de Bobbio de que a passagem de uma norma mais abrangente ("que abrange um certo genus") para uma norma derrogatória ("que abrange uma species do genus") "corresponde a uma exigência fundamental de justiça, (...) a um processo natural de diferenciação das categorias, e a uma descoberta gradual, por parte do legislador, dessa diferenciação" (cf. BOBBIO, Norberto. Teoria de Ordenamento Jurídico. 10a ed. Brasília: Universidade de Brasília, 1999. p. 96)

${ }^{906}$ Cf. Exposição de Motivos n. 379/1986.
} 
Não se pretende promover aqui uma compilação exaustiva das conclusões dos seis capítulos desta dissertação, mas tão somente iluminar o caminho que leva a concluir pela importância de atentar-se para essa nova taxonomia. O estudo aponta o deslocamento de um modelo pautado na dicotomia entre companhias abertas e fechadas, para um sistema de companhias abertas de diferentes categorias, que ficam sujeitas a exigências distintas conforme, por exemplo, tenham ou não ações listadas em bolsa, ou acessem o mercado exclusivamente por meio de debêntures. Elas podem ou não ter promovido oferta pública de distribuição de valores mobiliários, e podem ou não ter promovido oferta pública para cancelamento do registro para negociação de ações e conversão para categoria de registro alternativa ${ }^{907}$. Em paralelo, temos as companhias incentivadas e as companhias fechadas - isto é, não registradas como abertas - que acessam o mercado sob dispensa de registro, sujeitas por isso a conjuntos de normas distintos. Em vista desse quadro, como bem aponta Tavares Guerreiro, "pode-se dizer, com absoluta certeza, que o modelo da companhia aberta brasileira é, hoje, diverso daquele que vigorava à época da promulgação da Lei"908.

Convém lembrar que, à época da promulgação das Leis n. 6.3876/1976 e 6.404/1976, vivia-

${ }^{907}$ Exsurge também desse estudo a importância do emprego cuidadoso da terminologia da lei, em vista dessa nova taxonomia. A "companhia aberta" das Leis n. 6.385/1976 e 6.404/1976 não se confundia com a "sociedade anônima de capital aberto" da lei fiscal, nem mesmo com a ideia muito difundida na prática de "companhia de capital aberto" (afinal, há também companhias abertas com "capital fechado", cujo registro não autoriza a distribuição pública de valores mobiliários de capital e que acessam o mercado por meio da oferta pública de debêntures, por exemplo). A frequente confusão entre esses termos na prática parece contribuir para a maior difusão da percepção em torno da companhia aberta que a identifica com a ideia de ampla dispersão acionária, percepção essa que não reflete a realidade de grande parte das companhias abertas e não se coaduna com a abrangência da definição legal. Apesar de o Direito, por certo, não se reduzir à dimensão linguística (cf. FERRAZ JR., Tercio Sampaio. Teoria da norma jurídica: ensaio de pragmática da comunicação normativa. $5^{\text {a }}$ ed. São Paulo: Atlas, 2016. p. 8), ainda assim é interessante notar como a dificuldade de que se trata se revela já nessa dimensão. Nessa linha, destaca Genaro Carrió, ao tratar da ambiguidade da linguagem natural: "Entre el área de los casos claros y la de los inequívocamente excluidos se extiende una imprecisa zona de fronteras, no susceptible de deslinde, como no sea por una decisión arbitraria. (...) Todas las palabras que se usan para hablar del mundo, para aludir a los fenómenos de la realidad, participan de las mismas características. Respecto de todas ellas vale la siguinte metáfora esclarecedora. Hay un foco de intensidad luminosa donde se agrupan los ejemplos típicos, aquellos frente a los cuales no se duda que la palabra es aplicable. Hay una mediata zona de oscuridad circundante donde caen los casos en los que no se duda que no los es. El tránsito de una zona a outra es gradual; entre la total luminosidad y la oscuridad total hay uma zona de penumbra sin limites precisos. Paradójicamente ella no empieza ni termina em ninguna parte, y sin embargo existe. Las palabras que diariamente usamos para aludir al mundo en que vivimos y a nosotros mismos llevan consigo esa imprecisa aura de imprecisión." (cf. CARRIÓ, Genaro R. Notas sobre derecho y lenguaje. $1^{\mathrm{a}}$ ed. Buenos Aires: Abeledo-Perrot, 1972. p. 31-32)

${ }^{908}$ Cf. GUERREIRO, José Alexandre Tavares. "Sociedade anônima: dos sistemas e modelos ao pragmatismo". In: CASTRO, Rodrigo Monteiro de. AZEVEDO, Luis André N. de Moura. (coord.). Poder de controle e outros temas de Direito societário e mercado de capitais. São Paulo: Quartier Latin, 2010. p. 23. Prossegue o autor: "E isso se se quiser conceder que, de fato, há um "novo” modelo, ou alguns novos "modelos" nesse campo. Basta que se preste atenção, por exemplo, aos fenômenos do controle compartilhado ou aos esquemas de composição de capital das sociedades que atuam no chamado Novo Mercado, mais abaixo referidos. $O$ desenho primitivo, a que a Lei dedicara, aparentemente, toda a sua energia, apaga-se progressivamente, substituindo-se por outras fórmulas articuladas." (p. 23-24) 
se ainda a transição da sociedade moderna para a contemporânea. É traço distintivo da era moderna a pretensão de criar modelos, de enquadrar a realidade em estruturas, contexto em que eram prezadas as dicotomias, muitas vezes instrumentalizadas por jogos de palavras (“abertas" e "fechadas", "públicas” e "privadas”). Já a transição para a contemporaneidade é marcada por certa diluição de modelos, pela busca de maior fluidez, nos mais diferentes setores. Uma modernidade líquida, como cunhou Bauman ${ }^{909}$.

Nesse sentido, os movimentos percebidos a partir do estudo empreendido parecem espelhar essas marcas da contemporaneidade. Revelam um distanciamento do antigo modelo, mais rigidamente demarcado, de acentuada polarização entre companhias abertas e fechadas, em prol de um sistema mais flexível, que permita reconfigurações quando justificável, em constante reconsideração e mais rápida renovação ${ }^{910}$. Em síntese, parecem pretender equilibrar a dose de artificialidade inerente às definições e estruturas jurídicas, no intento de aproximá-las ainda mais das transformações da realidade subjacente ${ }^{911}$.

Nesse ponto, da maior pertinência é a observação de Tavares Guerreiro no sentido de que " $o$ que parece ter tomado o lugar da fixidez dos sistemas e da imobilidade dos modelos é uma

909 "O que todas essas características dos fluidos mostram, em linguagem simples, é que os líquidos, diferentemente dos sólidos, não mantêm sua forma com facilidade. Os fluidos, por assim dizer, não fixam o espaço nem prendem o tempo. Enquanto os sólidos têm dimensões espaciais claras, mas neutralizam o impacto e, portanto, diminuem a significação do tempo (resistem efetivamente a seu fluxo ou o ternam irrelevante), os fluidos não se atêm muito a qualquer forma e estão constantemente prontos (e propensos) a mudá-la; assim, para eles, o que conta é o tempo, mais do que o espaço que lhes toca ocupar; espaço que, afinal, preenchem apenas “por um momento”. Em certo sentido, os sólidos suprimem o tempo; para os líquidos, ao contrário, o tempo é o que importa. Ao descrever os sólidos, podemos ignorar inteiramente o tempo; ao descrever os fluidos, deixar o tempo de fora seria um grave erro. Descrições de líquidos são fotos instantâneas, que precisam ser datadas. (...) Essas são as razões para considerar "fluidez" ou "liquidez" como metáforas adequadas quando queremos captar a natureza da presente fase, nova de muitas maneiras, na história da modernidade." (cf. BAUMAN, Zygmunt. Modernidade líquida. Trad. Plínio Dentzien. Rio de Janeiro: Zahar, 2001. p. 8-9)

${ }^{910}$ Por reflexo, torna-se inerente a estudos como o presente, que se debruçam sobre a matéria, o risco de mais rápida desatualização, diante da mais frequente revisão do arcabouço normativo.

${ }^{911}$ Vale lembrar que essa dose de artificialidade era acusada já na transição de um modelo uniforme, que não fazia distinção entre companhias abertas e fechadas, para um modelo mais segmentado. Para ilustrar o ponto, cita-se, por todos, a lição de Comparato: “(...) o atual estatuto da sociedade anônima, na generalidade dos países, encontra-se inadequado ao fenômeno da macro-emprêsa. O divórcio entre o direito estatuído e o direito vivido, nesta matéria, só tende aliás a acentuar-se, com a inelutável evolução econômica. Constitui, portanto, tarefa primordial do jurista a busca de soluções novas para os problemas que esta última não deixa de pôr. Tais soluções, porém, só podem ser delineadas a partir do superamento do estatuto artificialmente unitário da sociedade anônima, com o indispensável esfôrço de distinção doutrinária que um empreendimento dessa ordem pressupõe, preliminarmente." (cf. COMPARATO, Fábio Konder. Aspectos jurídicos da macroemprêsa. São Paulo: Revista dos Tribunais, 1970, p. 63) Nesse sentido, há certa identidade entre o quadro atual e a preocupação enfrentada na década de 1970, em particular quanto ao desafio de aproximar a disciplina jurídica das companhias da realidade subjacente, à luz da propagada defesa de que "one size does not fit all". 
espécie de pragmatismo que força soluções com um mínimo de sacrifício à ortodoxia"912. A plasticidade das Leis n. 6.385/1976 e 6.404/1976 permitiu, e ainda permite, a acomodação de soluções mais flexíveis, para atender a problemas decorrentes de sua original rigidez estrutural e para fazer face a novos desafios e necessidades do dinâmico mercado por elas disciplinado.

Esta dissertação buscou retratar a companhia aberta, para tanto percorrendo os contornos de sua disciplina jurídica, com olhos voltados mais à operacionalidade do que à essência de sua definição legal. Apesar de restar parcialmente comprometida a função instrumental a ela originalmente confiada, de atrair e circunscrever o universo de destinatários dessa disciplina, isso não retira dos diplomas em questão seu inegável valor e qualidade para abarcar a nova realidade. Concluímos corroborando a lição de Tavares Guerreiro de que "o "sistema", mesmo desfigurado, não retira da Lei seu enorme potencial de servir às necessidades reais da economia e do mercado" $" 913$.

Nesse diapasão, a constatação merece nota menos como crítica, e mais como registro das transformações percebidas nessa transição de uma disciplina fortemente centrada no modelo traçado a partir da definição legal de companhia aberta para outro mais fluido. A nova matriz de possibilidades de acesso ao mercado que nasceu das iniciativas comentadas de adequação dessa disciplina torna mais complexa a resposta à pergunta formulada para introduzir o tema desta dissertação (“O que é a companhia aberta segundo o Direito brasileiro?”).

A perspectiva histórica parece importante para a compreensão do contexto e sentido original que se pretendeu atribuir a determinadas normas, e sua eventual ressignificação diante da nova realidade. Ao mesmo tempo, a compreensão da estrutura original desses diplomas contribuiu para a identificação de certas barreiras ainda opostas à flexibilização dessa disciplina, bem como para a visualização do quadro assimétrico, ou mesmo assistemático, resultante de alterações pontuais conduzidas sem o necessário cuidado com o sistema da lei ${ }^{914}$. Para estudos futuros sobre o tema parece importante atentar para essa nova realidade

${ }^{912}$ Cf. GUERREIRO, José Alexandre Tavares. "Sociedade anônima: dos sistemas e modelos ao pragmatismo". In: CASTRO, Rodrigo Monteiro de. AZEVEDO, Luis André N. de Moura. (coord.). Poder de controle e outros temas de Direito societário e mercado de capitais. São Paulo: Quartier Latin, 2010. p. 27.

${ }^{913}$ Cf. GUERREIRO, José Alexandre Tavares. "Sociedade anônima: dos sistemas e modelos ao pragmatismo". In: CASTRO, Rodrigo Monteiro de. AZEVEDO, Luis André N. de Moura. (coord.). Poder de controle e outros temas de Direito societário e mercado de capitais. São Paulo: Quartier Latin, 2010. p. 24.

${ }^{914}$ Como destaca Tavares Guerreiro, "[a] manutenção da estrutura fundamental da Lei contribui, sem dúvida, para garantia da estabilidade, entendida como necessária ao crescimento dos mercados e à confiabilidade nas suas instituições". (cf. GUERREIRO, José Alexandre Tavares. "Sociedade anônima: dos sistemas e modelos ao pragmatismo". In: CASTRO, Rodrigo Monteiro de. AZEVEDO, Luis André N. de Moura. (coord.). 
e para os caminhos que até ela conduzem. Foi essa dupla visão - retrospectiva e prospectiva, de que falamos na Introdução ${ }^{915}$ - que buscamos oferecer no tocante às normas selecionadas, em especial aquelas relacionadas à temática do registro.

A imagem da "fronteira", que, no plural, se segue a objeto e estrutura no título desta dissertação, parece útil para conotar os rearranjos demarcatórios promovidos por esses movimentos e tendências, consubstanciando e destacando traços decorrentes do confronto entre os contornos originais e os desenvolvimentos mais recentes dentro dessa disciplina jurídica, visíveis a partir da articulação de diferentes normas. Empregamo-la aqui no intuito de demonstrar que o retrato da companhia aberta em sua dimensão jurídica nasce da necessária conjugação dessas chamadas fronteiras, e sinaliza a devida preocupação de harmonização nessa tarefa de conjugação. Com isso pretendeu-se promover reflexão sobre o tema sob essa ótica. Afinal, deve o Direito estar a serviço do interesse público, como ferramenta de concretização. Nessa toada, definições jurídicas não devem guardar pretensão de imutabilidade, e sim cuidar de sua instrumentalidade, em especial, face à nova realidade, de fronteiras fluidas.

Poder de controle e outros temas de Direito societário e mercado de capitais. São Paulo: Quartier Latin, 2010. p. 27)

915 Cf. REALE, Miguel. Lições preliminares de Direito. 27ª ed. São Paulo: Saraiva, 2006. p. 293-294. 


\section{REFERÊNCIAS}

ABRÃO, Nelson. Companhias abertas e fechadas no sistema da Lei 6.404, de 1976. Revista de Direito Mercantil, Industrial, Econômico e Financeiro, São Paulo, n. 24, p. 4549, 1976.

ABREU, Jorge M. Coutinho de. Portugal: synopsis on corporate governance. In: FLECKNER, Andreas M. HOPT, Klaus J. Comparative corporate governance: a functional and international analysis. Cambridge University Press, 2013.

ALMEIDA, Carolina Amaral de; BAZILIO, Juliana Kramer. Liquidez do mercado secundário de debêntures: dinâmica recente, fatores determinantes e iniciativas. Revista do BNDES, n. 44, p. 175-223, 2015.

ANBIMA; B3. Mercado de capitais: caminho para o desenvolvimento. 2018. Disponível em: https://www.anbima.com.br/pt_br/especial/mercado-de-capitais-caminho-para-odesenvolvimento.htm. Acesso em: 10 jul. 2019.

ANBIMA. Boletim de Mercado de Capitais, dezembro/2019. Disponível em: https://www.anbima.com.br/pt_br/informar/relatorios/mercado-de-capitais/boletim-demercado-de-capitais/emissoes-domesticas-registram-aumento-de-59-3-em-2019.htm. Acesso em: 08 jan. 2020.

ANNUNZIATA, Filippo. La disciplina del mercato mobiliare. 3. ed. Torino: Giappichelli, 2004.

ARAÚJO, Rodolfo. Brésil. In: ROTONDI, M (coord.). Enquête comparative sur les sociétés par actions. Holanda: Perugia, 1974. p. 429-453.

ARMOUR, John. HANSMANN, Henry. KRAAKMAN, Reinier. PARGENDLER, Mariana. What is corporate law? In: KRAAKMAN, Reinier. ARMOUR, John. DAVIES, Paul. ENRIQUES, Luca. HANSMANN, Henry. HERTIG, Gerald. HOPT, Klaus. KANDA, Hideki. PARGENDLER, Mariana. RINGE, Wolf-Georg. ROCK, Edward. The Anatomy of Corporate Law. $3^{\text {a }}$ ed. Oxford: Oxford University Press, 2017. p. 5-28.

ARRUDA, Maria Clara da Silveira Villasboas. Companhia aberta x companhia fechada. In: Revista de Direito Mercantil, Industrial, Econômico e Financeiro. n. 65. São Paulo: Revista dos Tribunais, 1987. p. 42-63. 
ARSHT, Samuel. STAPLETON, Walter. Analysis of the New Delaware Corporation Law. New Jersey: Prentice-hall, 1967.

ASCARELLI, Tullio. Problemas das sociedades anônimas e Direito comparado. 2. ed. São Paulo: Saraiva, 1969.

ASQUINI, Alberto. Perfis da empresa. 1943. Tradução de Fábio Konder Comparato. In: Revista de Direito Mercantil, Industrial, Econômico e Financeiro, n. 104, ano XXXV (nova série), outubro-dezembro/1996. p. 109-126.

AZEVEDO, Simone. A nova 202. Revista Capital Aberto. São Paulo, setembro de 2003. Disponível em: https://capitalaberto.com.br/temas/a-nova-202/. Acesso em: 10 set. 2019.

BACHA, Edmar Lisboa; OLIVEIRA FILHO, Luiz Chrysostomo de. Introdução. In: Mercado de capitais e crescimento econômico: lições internacionais, desafios brasileiros. Rio de Janeiro: Contra Capa Livraria, 2007. p. 13-30.

BACHMANN, Gregor. EIDENMÜLLER, Horst. ENGERT, Andreas. FLEISCHER, Holger. SCHÖN, Wolfgang. Regulating the closed corporation. Berlin/Boston: Walter de Gruyter, 2014.

BAINBRIDGE, Stephen M. Dodd-Frank: quack federal corporate governance round II. 2010. UCLA School of Law, Law-Econ Research Paper n. 10-12. Disponível em: https://papers.ssrn.com/sol3/papers.cfm?abstract_id=1673575. Acesso em: 02 jan. 2020.

BAINBRIDGE, Stephen M. The corporate governance provisions of Dodd-Frank. 2010. UCLA School of Law, Law-Econ Research Paper n. 10-14. Disponível em: https://ssrn.com/abstract=1698898. Acesso em: 02 jan. 2020.

BANDEIRA DE MELLO, Celso Antonio. Prestação de serviços públicos e administração indireta. São Paulo: Revista dos Tribunais, 1973.

BANNER, Stuart. Anglo-american securities regulation: cultural and political roots, 16901860. Cambridge: Cambridge University Press, 1998.

BARBOSA, Marcelo. PEREIRA, Catarina. Custos de observância e o equilíbrio regulatório: a CVM e os bastidores do projeto de redução do custo de observância. 2018. Disponível em: https://www.jota.info/tributos-e-empresas/mercado/custos-de-observanciae-o-equilibrio-regulatorio-19122018. Acesso em: 25 mar. 2019. 
BARRETO FILHO, Oscar. Novos rumos para a sociedade anônima. As emprêsas no contexto social. In: Revista da Faculdade de Direito da Universidade de São Paulo, São Paulo, v. 66, p. 161-174, 1971.

BARRETO FILHO, Oscar. Seminário sobre a reforma das sociedades anônimas, promovido pelo Instituto dos Advogados Brasileiros. In: Revista de Direito Mercantil, Industrial, Econômico e Financeiro. n. 7. São Paulo: Revista dos Tribunais, 1972.

BATALHA, Wilson de Souza Campos. Sociedades anônimas e mercado de capitais. Vol. I. Rio de Janeiro: Forense, 1973.

BAUMAN, Zygmunt. Modernidade líquida. Trad. Plínio Dentzien. Rio de Janeiro: Zahar, 2001.

BERLE, Adolf A. MEANS, Gardiner C. The modern corporation \& private property. New Brunswick: Transaction Publishers, 2007.

BERTÃO, Naiara. Valor de mercado de empresas na bolsa ultrapassa R $\$ 4$ trilhões pela $1^{\mathrm{a}}$ vez. In: Valor Econômico. 19 de julho de 2019. Disponível em:

https://valorinveste.globo.com/mercados/renda-variavel/noticia/2019/07/19/valor-demercado-de-empresas-na-bolsa-ultrapassa-r-4-trilhoes-pela-1a-vez.ghtml. Acesso em: 19 jul. 2019.

BOBBIO, Norberto. Teoria da Norma Jurídica. $3^{\mathrm{a}}$ ed. Bauru: Edipro, 2005.

BOBBIO, Norberto. Teoria de Ordenamento Jurídico. $10^{\text {a }}$ ed. Brasília: Universidade de Brasília, 1999.

BOURDIEU, Pierre. O Poder Simbólico. Trad. Fernando Tomaz. 11. ed. Rio de Janeiro: Bertrand Brasil, 2007.

BOVESPA. A bolsa dos brasileiros: uma breve história da Bovespa e do mercado de capitais. São Paulo: Bovespa, 2005.

BULHÕES, Carlos Eduardo. Comentários aos arts. $4^{\circ}$ e $4^{\circ}$-A da Lei das Sociedades Anônimas. In: Revista de Direito Bancário e do Mercado de Capitais. N. 23. São Paulo: Revista dos Tribunais, janeiro-março de 2004. p. 106-129.

BUSCHINELLI, Gabriel Saad Kik. Artigos 19 \& 20. In: CODORNIZ, Gabriela. PATELLA, Laura (coords.). Comentários à Lei do Mercado de Capitais - Lei n. 6.385/76. São Paulo: Quartier Latin, 2015. p. 379-425. 
CÂMARA, Paulo. Manual de Direito dos Valores Mobiliários. $2^{\mathrm{a}}$ ed. Coimbra: Almedina, 2011.

CANTIDIANO, Luiz Leonardo. “A privatização e o mercado de capitais". In: Direito societário \& mercado de capitais. Rio de Janeiro: Renovar, 1996. p. 169-182.

CANTIDIANO, Luiz Leonardo. "Alteração na Lei das Sociedades por Ações - o Substitutivo do Deputado Emerson Kapaz”. In: MOSQUERA, Roberto Quiroga (coord.). Aspectos atuais do Direito do mercado financeiro e de capitais. $2^{\circ}$ vol. São Paulo: Dialética, 2000. p. 141-160.

CANTIDIANO, Luiz Leonardo. Reforma da Lei das S.A. comentada. Rio de Janeiro: Renovar, 2002.

CANTIDIANO, Luiz Leonardo. "O desenvolvimento do mercado de capitais". In: Revista de Direito Empresarial IBMEC. Rio de Janeiro: Lumen Juris, 2003. p. 1-7.

CANTIDIANO, Luiz Leonardo. Aspectos regulatórios do mercado de capitais. In: Mercado de capitais e crescimento econômico: lições internacionais, desafios brasileiros. Rio de Janeiro / São Paulo: Contra Capa Livraria / ANBID, 2007. p. 217-224.

CARVALHOSA, Modesto. "Notícia sobre a reforma de lei de sociedades anônimas projeto do Deputado Emerson Kapaz”. In: MOSQUERA, Roberto Quiroga (coord.). Aspectos atuais do Direito do mercado financeiro e de capitais. $2^{\circ}$ vol. São Paulo: Dialética, 2000. p. 177-188.

CARVALHOSA, Modesto. EIZIRIK, Nelson. A nova lei das S/A. São Paulo: Saraiva, 2002.

CARVAlHOSA, Modesto. Comentários à Lei de Sociedades Anônimas. $4^{\mathrm{a}}$ ed. São Paulo: Saraiva, 2002.

CARRIÓ, Genaro R. Notas sobre derecho y lenguaje. $1^{\mathrm{a}}$ ed. Buenos Aires: AbeledoPerrot, 1972.

CASTRO, Rodrigo R. Monteiro de. Abertura e fechamento de capital. In: CASTRO, Rodrigo R. Monteiro de. ARAGÃO, Leandro Santos de. (coords.). Sociedade anônima: 30 anos da Lei 6.404/76. São Paulo: Quartier Latin, 2007. p. 428-478. 
CASTRO, Rodrigo R. Monteiro de. Capítulo 5 - A sociedade por ações brasileira. In: ARAÚJO, Danilo Borges do Santos Gomes de. Regulação brasileira do mercado de capitais. São Paulo: Saraiva, 2015. p. 203-222.

CEREZETTI, Sheila Christina Neder. Artigo 4. In: CODORNIZ, Gabriela. PATELLA, Laura (coords.). Comentários à Lei do Mercado de Capitais - Lei n. 6.385/76. São Paulo: Quartier Latin, 2015. p. 115-131.

CHEDIAK, Julian Fonseca Peña. A reforma do mercado de valores mobiliários. In: LOBO, Jorge (coord.). Reforma da lei das sociedades anônimas: inovações e questões controvertidas da Lei n. 10.303, de 31.10.2001. Rio de Janeiro: Forense, 2002. p. 525-551.

CLARK, Robert Charles. Corporate Law. Boston: Little, Brown and Company, 1986.

CODORNIZ, Gabriela. PATELLA, Laura. COPOLA, Marina. Artigo $2^{\circ}$. In: CODORNIZ, Gabriela. PATELLA, Laura (coords.). Comentários à Lei do Mercado de Capitais - Lei $n$. 6.385/76. São Paulo: Quartier Latin, 2015. p. 47-102.

COFFEE, JR. John C. The mandatory/enabling balance in corporate law: an essay on the judicial role. In: ROMANO, Roberta. Foundations of corporate law. New York: Foundation Press, 1993. p. 111-113.

COFFEE JR., John. The Challenge of the Semi-Public Company, 2013. Disponível em: http://clsbluesky.law.columbia.edu/2013/04/01/the-challenge-of-the-semi-publiccompany/. Acesso em: 30 jun. 2018.

COFFE JR., John. The irrepressible myth that SEC overregulation has chilled IPOs. Disponível em: http://clsbluesky.law.columbia.edu/2018/05/29/the-irrepressible-myth-thatsec-overregulation-has-chilled-ipos/. Acesso em: 03 jan. 2020.

COFFE JR., John. Gatekeepers: the professions and corporate governance. Oxford: Oxford University Press, 2006.

COFFEE JR., John. The Political Economy of Dodd-Frank: Why Financial Reform Tends to be Frustrated and Systemic Risk Perpetuated, 2012. Disponível em:

https://ssrn.com/abstract=1982128. Acesso em: 18 jan. 2020.

COMPARATO, Fábio Konder. Aspectos jurídicos da macro-emprêsa. São Paulo: Revista dos Tribunais, 1970. 
COMPARATO, Fábio Konder. O poder de controle na sociedade anônima. São Paulo: Revista dos Tribunais, 1976.

COMPARATO, Fábio Konder. A natureza da sociedade anônima e a questão da derrogabilidade das regras legais de quórum nas assembleias gerais e reuniões do conselho de administração. In: Novos Ensaios e Pareceres de Direito Empresarial. Rio de Janeiro: Forense, 1981. p. 116-131.

COMPARATO, Fábio Konder. O direito ao dividendo nas companhias fechadas. In: Direito Empresarial. São Paulo: Saraiva, 1995. p. 158-165.

COMPARATO, Fábio Konder. Cancelamento voluntário de registro de companhia aberta. Aquisição de ações do próprio capital e abuso de controle”. In: Direito Empresarial. São Paulo: Saraiva, 1995. p. 103-119.

CONAC, Pierre-Henri. France: the permanent reform of corporate governance. In: FLECKNER, Andreas M. HOPT, Klaus J. Comparative corporate governance: a functional and international analysis. Cambridge University Press, 2013.

CORDEIRO, Ari. Ações e reações no mercado de capitais. Rio de Janeiro: APEC, 1977.

COSTA, Philomeno J. da. Anotações às companhias. Vol. I. São Paulo: Revista dos Tribunais, 1980.

COURET, Alain. NABASQUE, Hervé le. COQUELET, Marie-Laure. GRANIER, Thierry. PORACCHIA, Didier. RAYNOUARD, Arnaud. REYGROBELLET, Arnaud. ROBINE, David. Droit financier. $1^{\text {a }}$ ed. Paris: Dalloz, 2008.

COX, James D. HILLMAN, Robert W. LANGEVOORT, Donald C. Securities regulation: cases and materials. $5^{\text {a }}$ ed. New York: Aspen Publishers, 2006.

COZIAN, Maurice. VIANDIER, Alain. DEBOISSY, Florence. Droit des sociétés. $29^{\mathrm{a}}$ ed. Paris: Lexis Nexis, 2016.

CVM. Planejamento Estratégico: construindo a CVM de 2023. Versão 2019. Disponível em: http://www.cvm.gov.br/menu/acesso_informacao/planos/estrategico/estrategico.html. Acesso em: 08 jul. 2019.

CVM. O mercado de divida corporativa no Brasil: Uma análise dos desafios e propostas para seu desenvolvimento. 2019. Disponível em:

http://www.cvm.gov.br/export/sites/cvm/menu/acesso_informacao/serieshistoricas/estudos 
/anexos/estudo_cvm_mercado_de_divida_corporativa_no_Brasil.pdf. Acesso em: 15 abr. 2019.

CVM. Deliberação CVM 809 traz inovações relacionadas ao registro de ofertas públicas: medidas fazem parte do projeto de redução dos custos de observância e estão em linha com as práticas internacionais. 2019. Disponível em:

http://www.cvm.gov.br/noticias/arquivos/2019/20190219-2.html. Acesso em: 25 mar. 2019.

CVM. Custo de Observância Regulatória. Disponível em:

http://www.cvm.gov.br/legislacao/custo_observancia.html Acesso em: 25 mar. 2019.

CVM. Agenda Regulatória CVM 2019. 4 de fevereiro de 2019. Disponível em: http://www.cvm.gov.br/noticias/arquivos/2019/20190204-1.html Acesso em: 21 mar. 2019.

CVM. CVM suspende o registro de 1122 companhias incentivadas. 1 de outubro de 2007. Disponível em: http://www.cvm.gov.br/noticias/arquivos/2007/20071001-2.html. Acesso em: 17 set. 2009.

CVM. CVM cancela de ofício o registro de 249 companhias incentivadas. 30 de setembro de 2008. Disponível em: http://www.cvm.gov.br/noticias/arquivos/2008/20080930-1.html. Acesso em: 17 set. 2019.

CVM. CVM exclui de seu cadastro 649 companhias beneficiárias de incentivos fiscais. 23 de janeiro de 2008. Disponível em:

http://www.cvm.gov.br/noticias/arquivos/2008/20080123-1.html. Acesso em: 17 set. 2019.

CVM. CVM cancela de ofício o registro de 812 companhias incentivadas. 14 de fevereiro de 2012. Disponível em: http://www.cvm.gov.br/noticias/arquivos/2012/20120214-1.html. Acesso em: 18 set. 2019.

CVM. Crowdfunding de investimento. Rio de Janeiro: CVM, 2019. Disponível em: www.investidor.gov.br. Acesso em: 06 out. 2019.

CVM. Boletim de Mercado, ano I, n. 1, nov. 2013. Disponível em: http://www.cvm.gov.br/publicacao/boletimmercado.html. Acesso em: 10 jul. 2019.

CVM. Boletim de Mercado, ano 7, n. 74, dez. 2019. Disponível em: http://www.cvm.gov.br/publicacao/boletimmercado.html. Acesso em: 02 jan. 2020. 
CVM. Regime Informacional e Ofertas Públicas estão na Agenda Regulatória CVM 2020. Disponível em: http://www.cvm.gov.br/noticias/index.html. Acesso em: 08 jan. 2020.

DAVIES, Paul. Gower and Davies' principles of modern company law. $8^{\mathrm{a}}$ ed. Londres: Sweet \& Maxwell, 2008.

DAVIES, Paul. Introduction to Company Law. $2^{\text {a }}$ ed. Oxford: Oxford University Press, 2010.

DOUGLAS, William O. BATES, George E. “The Federal Securities Act of 1933”. 1933. In: MILLER, Geoffrey P. Economics of Securities Law. Vol. I. Nova York: Edward Elgar, 2016. p. 171-217.

DUARTE, Soraia. Ganhos potencializados com a isenção de IR. Valor Econômico. 18 de abril de 2019. Disponível em: https://www.valor.com.br/financas/6216545/ganhospotencializados-com-isencao-de-ir. Acesso em: 18 abr. 2019.

DYCK, Alexander. ZINGALES, Luigi. Private benefits of control: an international comparison. In: Journal of Finance, Vol. LIX, n. 2. 2004. p. 537-600.

EASTERBROOK, Frank H. FISCHEL, Daniel R. Mandatory disclosure and the protection of investors. In: ROMANO, Roberta. Foundations of corporate law. New York:

Foundation Press, 1993. p. 295-300.

ECKERT, Robert J. WELLENS, David R. A comparison of the close corporation statutes of Delaware, Florida and New York. In: University of Miami Law Review, 515, 1969. p. 515-530.

EIZIRIK, Nelson Laks. O papel do Estado na regulação do mercado de capitais. Rio de Janeiro: IBMEC, 1977.

EIZIRIK, Nelson Laks. Aspectos modernos do direito societário. Rio de Janeiro: Renovar, 1992.

EIZIRIK, Nelson. Reforma das S.A. e do mercado de capitais. Rio de Janeiro: Renovar, 1997.

EIZRIK, Nelson. Regime jurídico do mercado de capitais. Modificações introduzidas pela Lei n. 9.457/97. In: BULGARELLI, Waldírio (coord.). Reforma da lei das sociedades por ações. São Paulo: Pioneira, 1998. p. 83-107. 
EIZIRIK, Nelson. GAAL, Ariádna. PARENTE, Flávia. HENRIQUES, Marcus de Freitas. Mercado de capitais: regime jurídico. 3ª ed. Rio de Janeiro: Renovar, 2011.

EIZIRIK, Nelson. A Lei das S/A comentada. $2^{\mathrm{a}}$ ed. Quartier Latin: São Paulo, 2015.

EIZIRIK, Nelson. A oferta pública de distribuição de valores mobiliários. In: Direito societário. Estudos e pareceres. São Paulo: Quartier Latin, p. 2015. p. 427-450.

ENRIQUES, Luca. GILOTTA, Sergio. Disclosure and financial Market regulation. In: MOLONEY, Niamh. FERRAN, Eilís. PAYNE, Jennifer. The Oxford handbook of financial regulation. Oxford: Oxford University Press, 2015.

ENRIQUES, Luca. HERTIG, Gerald. KRAAKMAN, Reinier. ROCK, Edward. Corporate law and securities market. In: KRAAKMAN, Reinier. ARMOUR, John. DAVIES, Paul. ENRIQUES, Luca. HANSMANN, Henry. HERTIG, Gerald. HOPT, Klaus. KANDA, Hideki. PARGENDLER, Mariana. RINGE, Wolf-Georg. ROCK, Edward. The Anatomy of Corporate Law. $3^{\text {a }}$ ed. Oxford: Oxford University Press, 2017. p. 243-266.

ESMA. Investment-based crowdfunding: insights from regulators in the EU. Maio, 2015. Disponível em: https://www.esma.europa.eu/sites/default/files/library/2015/11/esma-2015856_ann_1_esma_response_to_ec_green_paper_on_cmu_-_crowdfunding_survey.pdf. Acesso em: 19 dez. 2019.

FERRAZ JR., Tercio Sampaio. Teoria da norma jurídica: ensaio de pragmática da comunicação normativa. $5^{\text {a }}$ ed. São Paulo: Atlas, 2016.

FALCÃO, Marina. CVM quer limpar cadastro de empresas inadimplentes. In: Valor Econômico, 21 de junho de 2011.

FERREIRA, Waldemar. O estatuto das sociedades anônimas brasileiras. In: Istituto di diritto commerciale comparato A. Sraffa dell'Università Bocconi di Milano. La società per azioni alla metà del secolo XX: studi in memoria di Angelo Sraffa. Pádua: Casa editrice Dott. Antonio Milani, 1961.

FLEISCHER, Holger. "A guide to german company law for international lawyers: distinctive features, particularities, idiosyncrasies". Max Planck Private Law Research Paper n. 15/8. Disponível em: https://ssrn.com/abstract=2597062. Acesso em: 05 dez. 2018. 
FREIRE, Jose Luiz Salles. A favor do vento. In: BERGER, Renato; CARVALHO, Rafael Villac Vicente de. LEITE, Leonardo Barém (coords.). 40 anos da Lei das S.A.: experiências, histórias e homenagens. São Paulo: Quartier Latin, 2016. p. 93-99.

GALGANO, Francesco. Trattato di Diritto Commerciale e di Diritto Publico Dell'Economia. Vol. 29. Pádua: Antonio Milani, 2003.

GILSON, Ronald J. HANSMANN, Henry. PARGENDLER, Mariana. Regulatory dualism as a development strategy: corporate reform in Brazil, the US, and the EU. 2010. Disponível em: http://ssrn.com/abstract=1541226. Acesso em: 09 nov. 2019.

GLUSHKOV, Denys. KHORANA, Ajay. RAU, P. Raghavendra. ZHANG, Jingxuan. Why Do Firms Go Public Through Debt Instead of Equity?. 2018. Disponível em: https://papers.ssrn.com/sol3/papers.cfm?abstract_id=2024375. Acesso em: 27 dez. 2019.

GUERREIRO, José Alexandre Tavares. Regime jurídico do capital autorizado. São Paulo: Saraiva, 1984.

GUERREIRO, José Alexandre Tavares. "Sociedade anônima: dos sistemas e modelos ao pragmatismo". In: CASTRO, Rodrigo Monteiro de. AZEVEDO, Luis André N. de Moura. (coord.). Poder de controle e outros temas de Direito societário e mercado de capitais. São Paulo: Quartier Latin, 2010. p. 19-28.

GUERREIRO, José Alexandre Tavares. Uma lembrança da época da Lei 6.404. In: BERGER, Renato; CARVALHO, Rafael Villac Vicente de. LEITE, Leonardo Barém (coords.). 40 anos da Lei das S.A.: experiências, histórias e homenagens. São Paulo: Quartier Latin, 2016. p. 89-92.

GUERREIRO, José Alexandre Tavares. “Administração: ordinária e extraordinária”. In: VENANCIO FILHO, Alberto. LOBO, Carlos Augusto da Silveira. ROSMAN, Luiz Alberto Colonna. Lei das S.A. em seus 40 anos. Rio de Janeiro: Forense, 2017. p. 199-216.

GOMES, Orlando. Em tema de sociedade anônima (1971). In: WALD, Arnoldo (org.). Direito empresarial: sociedades anônimas, vol. 3. São Paulo: Revista dos Tribunais, 2011. p. 101-113.

GRAU, Eros Roberto. Os conceitos jurídicos e a doutrina real do Direito. In: Revista da Faculdade de Direito, Universidade de São Paulo, vol. 77, 1982, p. 221-234. Disponível em: http://www.revistas.usp.br/rfdusp/article/view/669531982. Acesso em: 25 mar. 2019. 
HOFSTETTER, Karl. One size does not fit all: corporate governance for "controlled companies". Disponível em: https://papers.ssrn.com/sol3/papers.cfm?abstract_id=802705. Acesso em: 28 dez. 2018.

HOPT, Klaus J. Comparative corporate governance: the state of the art and international regulation. In: FLECKNER, Andreas M. HOPT, Klaus J. Comparative corporate governance: a functional and international analysis. Cambridge University Press, 2013.

HUBERT, Olivier. PINCE, Arnaud. France. In: The International Capital Markets Review. $9^{a}$ ed. The Law Reviews, dez. 2019. Disponível em:

https://thelawreviews.co.uk/edition/the-international-capital-markets-review-edition9/1211238/france. Acesso em: 28 dez. 2019.

IOSCO. Objectives and principles of securities regulation. 2017. Disponível em: https://www.iosco.org/library/pubdocs/pdf/IOSCOPD561.pdf. Acesso em: 27 dez. 2019.

ISRAELS, Carlos D. The close corporation and the law. In: Cornell Law Review, vol. 33, jun. 1948, p. 488-506.

JAEGER, Pier Giusto. DENOZZA, Francesco. TOFFOLETTO, Alberto. Appunti di diritto commerciale. Impresa e società. $7^{\text {a }}$ ed. Milão: Giuffrè, 2010.

JHERING, Rudolf von. L'Esprit du droit romain dan les diverses phases de son développement. Vol. III $3^{\text {a }}$ ed., Paris: A. Marescq, Aîné, 1887.

KANDIR, Antonio. A reforma da lei das S.A. e o desenvolvimento (2001). In: WALD, Arnoldo (org.). Direito empresarial: sociedades anônimas, vol. 3. São Paulo: Revista dos Tribunais, 2011. p. 39-47.

KANDIR, Antonio. Lei das S.A., uma conquista a comemorar. Folha de São Paulo, São Paulo, 21 set. 2001. Disponível em:

https://www1.folha.uol.com.br/fsp/opiniao/fz2109200110.htm. Acesso em: 31 jul. 2019.

KANDIR, Antonio. A nova CVM e a modernização da Lei das S.A. In: LOBO, Jorge (coord.). Reforma da lei das sociedades anônimas: inovações e questões controvertidas da Lei n. 10.303, de 31.10.2001. Rio de Janeiro: Forense, 2002. p. 3-9.

KAPAZ, Emerson. Lei das S.A.: uma contribuição decisiva. In: LOBO, Jorge (coord.). Reforma da lei das sociedades anônimas: inovações e questões controvertidas da Lei $\mathrm{n}$. 10.303, de 31.10.2001. Rio de Janeiro: Forense, 2002. p. 1-2. 
KELSEN, Hans. Teoria Pura do Direito. São Paulo: Martins Fontes, 2003.

KERSHAW, David. Company law in context: text and materials. Oxford: Oxford University Press, 2009.

KERSHAW, David. "Web chapter B: Issuing shares to the public". In: Company law in context: text and materials. $2^{\mathrm{a}}$ ed. Oxford: Oxford University Press, 2014.

KLEIN, William A. COFFEE, John C. PARTNOY, Frank. Business Organization and Finance: Legal and Economic Principles. New York: Foundation Press, 2010.

LA PORTA, Rafael. SILANES, Florencio Lopez de. SCHLEIFER, Andrei. VISHNY, Robert. Investor protection and corporate governance. 1999. Disponível em: https://ssrn.com/abstract=183908. Acesso em: 26 nov. 2019.

LACERDA, José Cândido Sampaio de. Manual das Sociedades por Ações. $3^{\mathrm{a}}$ ed. Rio de Janeiro: Freitas Bastos, 1974.

LAMY FILHO, Alfredo. BULHÕES PEDREIRA, José Luiz. A Lei das S.A.: pressupostos, elaboração, aplicação. $3^{\mathrm{a}}$ ed. Rio de Janeiro: Renovar, 1997.

LAMY FILHO, Alfredo. A reforma da lei de sociedades anônimas. In: Revista de Direito Mercantil, Industrial, Econômico e Financeiro. n. 7. São Paulo: Revista dos Tribunais, 1972. p. 123-158.

LAMY FILHO, Alfredo. BULHÕES PEDREIRA, José Luiz. Direito das companhias. $2^{\mathrm{a}}$ ed. Rio de Janeiro: Forense, 2017.

LAMY FILHO, Alfredo. A empresa, os minoritários e o mercado de capitais (2000). In: WALD, Arnoldo (org.). Direito empresarial: sociedades anônimas, vol. 8. São Paulo: Revista dos Tribunais, 2011.p. 71-77.

LAMY FILHO, Alfredo. Nota sobre o fechamento de companhia aberta. In: Temas de S.A.: exposições e pareceres. Rio de Janeiro: renovar, 2007. p. 219-221.

LANG, Henrique. MYANAKI, Cauê. CHAUFFAILLE. Gustavo. Capítulo 8 - Principais Agentes do Mercado. In: CVM. Direito do mercado de valores mobiliários. $1^{\mathrm{a}}$ ed. Rio de Janeiro: CVM, 2017. p. 299-336. 
LATTY, Elvin R. CLIFFORD, Donald. Estats Unis d'Amérique. In: ROTONDI, M. Enquête comparative sur les sociétés par actions. Holanda: Perugia, 1974.

LOBO, Carlos Augusto da Silveira. A alteração da lei de sociedades anônimas ora em discussão no Congresso Nacional (2000). In: WALD, Arnoldo (org.). Direito empresarial: sociedades anônimas, vol. 3. São Paulo: Revista dos Tribunais, 2011. p. 49-54.

LUCENA, José Waldecy. Das sociedades anônimas. Vol. I. Rio de Janeiro: Renovar, 2009.

MACHADO, Juliana. Aplicação de pessoa física na bolsa já é a maior em 13 anos. Valor Econômico. 18 de abril de 2019. Disponível em:

https://www.valor.com.br/financas/6216685/aplicacao-de-pessoa-fisica-na-bolsa-ja-emaior-em-13-anos. Acesso em: 18 abr. 2019.

MACHADO, Juliana. HIRATA, Lucas. Estrangeiro já tirou R\$ 19 bi da bolsa. In: Valor Econômico. 20 de agosto de 2019. Disponível em:

https://www.valor.com.br/financas/6397335/estrangeiro-ja-tirou-r-19-bi-da-bolsa. Acesso em: 20 ago. 2019.

MATTOS FILHO, Ary Oswaldo. PRADO, Viviane Muller. Tentativas de desenvolvimento do mercado acionário brasileiro desde 1964. In: LIMA, Maria Lúcia L. M. Padua (coord.). Direito e economia: 30 anos de Brasil. Tomo 2. São Paulo: Saraiva, 2012. p. 191-236.

MATTOS FILHO, Ary Oswaldo. O conceito de valores mobiliários. In: Rev. Adm. Empr. Rio de Janeiro, 25, abr./jun. 1985. p. 37-51.

MAXIMILIANO, Carlos. Hermenêutica e Aplicação do Direito. 19a ed. Rio de Janeiro: Forense, 2010.

MB ASSOCIADOS (SCHEINKMANN, José Alexandre et al). Desafios e oportunidades para o mercado de capitais brasileiro. BOVESPA, 2000.

McCAHERY, Joseph A. VERMEULEN, Erik P. Corporate governance of non-listed companies. Oxford University Press: Oxford, 2008.

MCPHERSON, Jemma Lohr. MARGENET-BAUDRY, Thomas. France. In: The Initial Public Offerings Law Review. $3^{\text {a }}$ ed. abr. 2019. Disponível em:

https://thelawreviews.co.uk/edition/the-initial-public-offerings-law-review-edition3/1189671/france. Acesso em: 28 dez. 2019. 
MERKT, Hanno. Internal and external corporate governance. In: FLECKNER, Andreas M. HOPT, Klaus J. Comparative corporate governance: a functional and international analysis. Cambridge University Press, 2013.

MILLER, Geoffrey P. Economics of Securities Law. Vol. I. Nova York: Edward Elgar, 2016.

MONTEIRO, Manuel. O regime jurídico das sociedades abertas em Portugal - breves notas. In: WALD, Arnoldo (org.). Direito empresarial: teoria geral, vol. 1. São Paulo: Revista dos Tribunais, 2011. p. 185-217.

MOREIRA, Ricardo. As companhias incentivadas e a CVM. In: Valor Econômico, 25 de abril de 2012. Disponível em: https://www.valor.com.br/legislacao/2631296/companhiasincentivadas-e-cvm. Acesso em: 12 ago. 2019.

MUNHOZ, Eduardo Secchi. Aquisição de controle na sociedade anônima. São Paulo: Saraiva, 2013.

MUNHOZ, Eduardo Secchi. "Influência do patrimonialismo na sociedade anônima importância dos mecanismos privados de efetivação dos deveres do acionista controlador e dos administradores". In: VENANCIO FILHO, Alberto. LOBO, Carlos Augusto da Silveira. ROSMAN, Luiz Alberto Colonna. Lei das S.A. em seus 40 anos. Rio de Janeiro: Forense, 2017. p. 129-156.

MÜSSNICH, Francisco A. Maciel. Reflexões sobre o direito de recesso na lei das sociedades por ações. In: LOBO, Jorge (coord.). Reforma da lei das sociedades anônimas: inovações e questões controversas da Lei n. 10.303, de 31.10.2001. Rio de Janeiro: Forense, 2002. p. 285-305.

OLIVEIRA, Fernando A. Albino de. Introdução. In: BERTOLDI, Marcelo (coord.). Reforma da lei das sociedades anônimas: comentários à Lei n. 10.303, de 31.10.00. $2^{\mathrm{a}}$ ed. São Paulo: Revista dos Tribunais, 2002. p. 11-25.

PAPINI, Roberto. Sociedade anônima e mercado de valores mobiliários. $2^{\mathrm{a}}$ ed. Rio de Janeiro: Forense, 1988.

PARENTE, Norma. "Principais inovações introduzidas pela Lei n.10.303, de 31 de outubro de 2001, à Lei de Sociedades por Ações". In: LOBO, Jorge (coord.). Reforma da lei das sociedades anônimas: inovações e questões controvertidas da Lei n. 10.303, de 31.10.2001. Rio de Janeiro: Forense, 2002. p. 11-49. 
PARGENDLER, Mariana. Cinco mitos sobre a história das sociedades anônimas no Brasil. Disponível em:

https://direitosp.fgv.br/sites/direitosp.fgv.br/files/arquivos/anexos/pargendler_cinco_mitos _sobre_a_historia_das_sa_homenagem_a_modesto_carvalhosa.pdf. Acesso em: 09 out.2019.

PARGENDLER, Mariana. How universal is the corporate form? Reflections on the dwindling of corporate attributes in Brazil. Disponível em:

https://papers.ssrn.com/sol3/papers.cfm?abstract_id=3126838. Acesso em: 04 abr. 2019.

PAREGENDLER, Mariana. Evolução do direito sociério: lições do Brasil. Sõ Paulo: Saraiva, 2013.

PENALVA SANTOS, J. A. Novos aspectos do mercado de capitais e outros trabalhos de direito comercial. Rio de Janeiro: Alba, 1968.

PENTEADO, Mauro. A Lei no 9.457/97 e a tutela dos direitos dos acionistas minoritários. In: BULGARELLI, Waldírio (coord.). Reforma da Lei das Sociedades por Ações. São Paulo: Pioneira, 1998. p. 9-82.

PINHEIRO, Vinicius. Grupo propõe acesso empresa média a debênture. Valor Econômico. 16 de setembro de 2013. Disponível em:

https://www.valor.com.br/financas/3270468/grupo-propoe-acesso-de-empresa-mediadebenture. Acesso em: 25 ago. 2019.

PINTO, Arthur E. GEVURTZ, Franklin A. Unites States: corporate governance for publicly traded corporations. In: FLECKNER, Andreas M. HOPT, Klaus J. Comparative corporate governance: a functional and international analysis. Cambridge University Press, 2013.

PITTA, André Grünspun. O regime de informação das companhias abertas. São Paulo: Quartier Latin, 2013.

PITTA, André Grünspun. Artigo 21. In: CODORNIZ, Gabriela. PATELLA, Laura (coords.). Comentários à Lei do Mercado de Capitais - Lei n. 6.385/76. São Paulo: Quartier Latin, 2015.

PITTA, Andrá Grünspun. A possibilidade de emissão de debêntures por sociedade limitada regida supletivamente pela lei das sociedades por ações. In: AZEVEDO, Luís André N. de Moura; CASTRO, Rodrigo R. Monteiro de (coord.). Sociedade Limitada Contemporânea. São Paulo: Quartier Latin, 2013. p. 500-517. 
PITTA, André Grünspun. "Mercados de acesso: recentes evoluções”. In: BOTREL, Sérgio. BARBOSA, Henrique. (coords.) Finanças corporativas: aspectos jurídicos e estratégicos. São Paulo: Atlas, 2016. p. 409-431.

PITTA, André Grünspun. A capitalização da empresa e o mercado de valores mobiliários. São Paulo: Quartier Latin, 2018.

PLESSIS, Jean Jacques du; HARGOVAN, Anil; BAGARIC, Mirko. Principles of contemporary corporate governance. 2 ed. Melbourne: Cambridge University Press, 2011.

POTENZA, Guilherme Perez. OLIVEIRA, Alexandre Edde Diniz. Regulando a inovação: o crowdfunding e o empreendedorismo brasileiro. In: Revista de Direito Empresarial. Vol. 15/2016. p. 69-107. Mai - Jun/2016.

PRITCHARD, Adam C. Chapter 40 - Corporate governance, capital markets, and securities law. In: GORDON, Jeffrey N. RINGE, Wolf-Georg. The Oxford Handbook of Corporate Law and Governance. Oxford: Oxford University Press, 2018. p. 1061-1083.

PUPO, Fábio et al. Indicada à CVM cita debate para trazer empresas menores ao mercado. Valor Econômico. 26 de fevereiro de 2019. Disponível em: https://www.valor.com.br/financas/6138745/indicada-cvm-cita-debate-para-trazerempresas-menores-ao-mercado. Acesso em: 25 mar. 2019.

RAGAZZI, Ana Paula. Mercado de dívida local cresce e começa a faltar bônus brasileiros no exterior. In: Valor Econômico. 31 de maio de 2019. Disponível em: https://www.valor.com.br/financas/6284403/mercado-de-divida-local-cresce-e-comecafaltar-bonus-brasileiros-no-exterior. Acesso em: 10 jul. 2019.

RAGAZZI, Ana Paula. TAUHATA, Sérgio. Oferta de ações bate recorde em 2019. In: Valor Econômico. 12 de julho de 2019. Disponível em: https://www.valor.com.br/financas/6341699/oferta-de-acoes-bate-recorde-em-2019. Acesso em: 12 jul. 2019.

REALE, Miguel. Lições preliminares de Direito. $27^{\mathrm{a}}$ ed. São Paulo: Saraiva, 2006.

REBELLO, Carlos. PITTA, André Grünspun. Instrução CVM 476 - Dez anos de liberdade com responsabilidade. In: Jota. Disponível em:

https://www.jota.info/paywall?redirect_to=//www.jota.info/opiniao-eanalise/artigos/instrucao-cvm-476-dez-anos-de-liberdade-com-responsabilidade-18022019. Acesso em: 05 set. 2019. 
REQUIÃO, Rubens. A sociedade anônima como “instituição". In: Revista de Direito Mercantil, Industrial, Econômico e Financeiro. n. 18. São Paulo: Revista dos Tribunais, 1976. p. 25-29.

REQUIÃO, Rubens. As sociedades de capital autorizado e de capital aberto. Disponível em: https://revistas.ufpr.br/direito/article/viewFile/6741/4825. Acesso em: 10 jun. 2019.

REQUIÃO, Rubens. Curso de Direito Comercial. Vol. 2. São Paulo: Saraiva, 1995.

REQUIÃO, Rubens. Curso de Direito Comercial. 25 ed. São Paulo: Saraiva, 2007.

REQUIÃO, Rubens. Comentários à Lei das Sociedades Anônimas. Vol. 1. São Paulo: Saraiva, 1980.

RIPERT, Georges. Aspects juridiques du capitalisme moderne. $2^{\mathrm{a}}$ ed. Paris: Librairie Générale de Droit et Jurisprudence, 1951.

RIPERT, Georges. ROBLOT, René. Traité de droit commercial. Vol. 2. 14a ed. Paris: LGDJ, 1994.

RITTER, Jay R. GAO, Xiaohui. ZHU, Zhongyan. Where Have All the IPOs Gone? 2013. Disponível em: https://ssrn.com/abstract=1954788. Acesso em: 03. jan. 2020.

ROCHA, Bruno. Limites e oportunidades do mercado de ações no Brasil. In: Mercado de capitais e crescimento econômico: lições internacionais, desafios brasileiros. Rio de Janeiro / São Paulo: Contra Capa Livraria / ANBID, 2007. p. 235-248.

ROCHA, João Pedro Gonçalves da. Capítulo II - Panorama do mercado de capitais (19611964). In: WALD, Arnoldo (coord.). O mercado de capitais. Rio de Janeiro: APEC, 1970. p. 29-60.

ROMANO, Roberta. State competition for corporate charters. In: ROMANO, Roberta. Foundations of corporate law. New York: Foundation Press, 1993. p. 84-90.

ROMANO, Roberta. The Sabanes-Oxley Act and the Making of Quack Corporate Governance. 2004. Disponível em: https://ssrn.com/abstract=596101. Acesso em: 02 jan. 2019.

ROSMAN, Luiz Alberto Colonna. VENÂNCIO FILHO, Alberto. Lembranças dos 40 anos. In: BERGER, Renato. CARVALHO, Rafael Villac Vicente de. LEITE, Leoonardo 
Barém. (coord.) 40 anos da Lei das S.A.: experiências, histórias e homenagens. São Paulo: Quartier Latin do Brasil, 2016. p. 22-25.

ROSS, Alf. Sobre los conceptos de "estado" y "órganos del estado" en derecho constitucional. El concepto de validez y otros ensayos. Buenos Aires: Centro Editor de America Latina, 1969. p. 83-106.

ROSS, Alf. Direito e Justiça. Bauru: Edipro, 2003.

ROTH, Günter H. KINDLER, Peter. The spirit of corporate law: core principles of corporate law in continental Europe. Munique: CH Beck, 2013.

SALLES, Marcos Paulo de Almeida. Os valores mobiliários na Lei das S/A. In: Revista de Direito Mercantil, Industrial, Econômico e Financeiro. n. 107. São Paulo: Revista dos Tribunais, 1997. p. 123-128.

SALOMÃO FILHO, Calixto. O novo direito societário. $2^{\text {a }}$ ed. São Paulo: Malheiros, 2002.

SANTANA, Maria Helena. O novo mercado. In: Novo Mercado and Its Followers: Case Studies in Corporate Governance Reform. The World Bank Group, 2008. Disponível em: http://www.b3.com.br/data/files/2C/46/8A/B7/88337610515A8076AC094EA8/Focus\%20 5_Capitulo\%20Novo\%20Mercado\%20_IFC\%202008_.pdf. Acesso em: 08 nov. 2019.

SCHINCARIOL, Juliana. CVM quer rever regra de BDR, oferta pública e formulário de referência. Valor Econômico. 5 de fevereiro de 2019. Disponível em:

https://www.valor.com.br/financas/6103799/cvm-quer-rever-regra-de-bdr-oferta-publica-eformulario-de-referencia. Acesso em: 25 mar. 2019.

SCHINCARIOL, Juliana. CVM cria caráter confidencial a ofertas. Valor Econômico. 20 de fevereiro de 2019. Disponível em: https://www.valor.com.br/financas/6126603/cvmcria-carater-confidencial-ofertas. Acesso em: 25 mar. 2019.

SCHINCARIOL, Juliana. CVM analisa mudanças nos EUA e na Europa para reformar regras de ofertas no Brasil. Valor Econômico. 27 dez. 2019. Disponível em: https://valor.globo.com/financas/noticia/2019/12/27/cvm-analisa-mudancas-nos-eua-e-naeuropa-para-reformar-regras-de-ofertas-no-brasil.ghtml. Acesso em 27 dez. 2019.

SILVA, Francisco Costa e. MARTINS NETO, Carlos. A utilização do instituto da incorporação de ações como forma de burlar a exigência legal de opa para fechamento de capital. 2007. Disponível em: https://www.bocater.com.br/wpcontent/uploads/2013/10/artigo-2008-062.pdf. Acesso em: 09 ago. 2019. 
SZTAJN, Rachel. Contrato de sociedade e formas societárias. São Paulo: Saraiva, 1989.

STONE, Ferdinand. Some comments on the american business corporation in midtwentieth century. In: Istituto di diritto commerciale comparato A. Sraffa dell'Università Bocconi di Milano. La società per azioni alla metà del secolo XX: studi in memoria di Angelo Sraffa. Pádua: Casa editrice Dott. Antonio Milani, 1961.

TANNOUS, Thiago Saddi. Proteção à liquidez no mercado de capitais brasileiro. São Paula: Quartier Latin, 2018.

TAUNAY, Visconde de. O encilhamento: cenas contemporâneas da bolsa do Rio de Janeiro em 1890, 1891 e 1892. $4^{\mathrm{a}}$ ed. Rio de Janeiro: Melhoramentos, 1947.

TEIXEIRA, Egberto L. GUERREIRO, José Alexandre Tavares. Das sociedades anônimas no Direito brasileiro. São Paulo: José Bushatsky, 1979.

TELLECHEA SILVA, Rodrigo. Sociedades anônimas fechadas: direitos individuais dos acionistas e cláusula compromissória estatutária superveniente. Tese de Doutorado. Orientador Prof. Associado Dr. Erasmo Valladão Azevedo e Novaes França. Universidade de são Paulo, Faculdade de Direito, São Paulo - SP, 2015.

TELLECHEA, Rodrigo. Artigo 22. In: CODORNIZ, Gabriela. PATELLA, Laura (coords.). Comentários à Lei do Mercado de Capitais - Lei n. 6.385/76. São Paulo: Quartier Latin, 2015. p. 483-518.

TELLECHEA, Rodrigo. Autonomia privada no direito societário. São Paulo: Quartier Latin, 2016.

TERRA, Aline de Miranda Valverde. Notas sobre o crowdfunding no direito brasileiro. Revista Eletrônica do Curso de Direito da UFSM, Santa Maria, RS, v. 13, n. 3, p. 11341160, dez. 2018. em: https://periodicos.ufsm.br/revistadireito/article/view/31176. Acesso em: 28 dez. 2019.

THOMAS, Jason. Where have all the public companies gone? In: Wall Street Journal, 16 nov. 2017. Diponível em: https://www.wsj.com/articles/where-have-all-the-publiccompanies-gone-1510869125. Acesso em: 02 jan. 2019.

TOKARS, Fábio. Comentários ao artigo $4^{\circ}$. In: BERTOLDI, Marcelo (coord.). Reforma da lei das sociedades anônimas: comentários à Lei n. 10.303, de 31.10.00. $2^{\mathrm{a}}$ ed. São Paulo: Revista dos Tribunais, 2002. 
TRINDADE, Marcelo. O papel da CVM e o mercado de capitais no Brasil. In: SADDI, Jairo (org.). Fusões e aquisições: aspectos jurídicos e econômicos. São Paulo: IOB, 2002. p. 295-329.

TRINDADE, Marcelo. Processo sancionador na CVM: limites e possibilidades. In: Lei das S.A. em seus 40 anos. Rio de Janeiro: Forense, 2017.p. 481-500.

TRUBEK, David M. GOUVEA VIEIRA, Jorge Hilário. SÁ, Paulo Fernandes de. $O$ mercado de capitais e os incentivos fiscais. Rio de Janeiro: TN-APEC, 1971.

TUNC, André. A french lawyer looks at american Corporation law and securities regulation. In: University of Pennsylvania Law Review. Vol. 130. Abr. 1982. No. 4. p. $757-$ 774.

VALVERDE, Trajano de Miranda. Sociedades por ações: comentários ao decreto-lei n. 2.627, de 26 de setembro de 1940. $2^{\text {a }}$ ed. Rio de Janeiro: Forense, 1953.

VENANCIO FILHO, Alberto. "Aspectos de evolução do Direito societário no Brasil”. In: VENANCIO FILHO, Alberto. LOBO, Carlos Augusto da Silveira. ROSMAN, Luiz Alberto Colonna. Lei das S.A. em seus 40 anos. Rio de Janeiro: Forense, 2017. p. 17-44.

VERÇOSA, Haroldo Malheiros Duclerc. As alterações da legislação societária e de mercado de capitais e suas implicações quanto à CVM. In: BULGARELLI, Waldírio (coord.). Reforma da lei das sociedades por ações. São Paulo: Pioneira, 1998. p. 193-210.

VERMEULEN, Erik P.M. "Chapter 31 - New metrics for corporate governance: shifting strategies in an aging IPO market". In: GORDON, Jeffrey N. RINGE, Wolf-Georg. The Oxford Handbook of Corporate Law and Governance. Oxford: Oxford University Press, 2018. p. 839-866.

VIDOR, George. A história da CVM pelo olhar de seus ex-presidentes. Rio de Janeiro: ANBIMA e BM\&FBOVESPA, 2016.

VIEIRA, Jorge Hilário Gouvêa. "Comissão de valores mobiliários". In: VENANCIO FILHO, Alberto. LOBO, Carlos Augusto da Silveira. ROSMAN, Luiz Alberto Colonna. Lei das S.A. em seus 40 anos. Rio de Janeiro: Forense, 2017. p. 435-453.

YAZBEK, Otavio. Regulação do mercado financeiro e de capitais. $2^{\mathrm{a}}$ ed. Rio de Janeiro: Elsevier, 2009. 
YAZBEK, Otavio. "As companhias abertas - sua caracterização, as vantagens e as desvantagens da abertura de capital". In: FINKELSTEIN, Maria Eugênia. PROENÇA, José Marcelo Martins (coords.). Direito societário: sociedades anônimas. $3^{\text {a }}$ ed. São Paulo: Saraiva, 2014.

YAZBEK, Otavio. "Em busca de um regime para os private placements no Brasil - ofertas públicas, ofertas privadas e ofertas públicas distribuídas com esforços restritos". In: BOTREL, Sérgio. BARBOSA, Henrique. (coords.) Finanças corporativas: aspectos jurídicos e estratégicos. São Paulo: Atlas, 2016. p. 173-192.

YAZBEK, Otavio. Introdução. In: CODORNIZ, Gabriela. PATELLA, Laura (coords.). Comentários à Lei do Mercado de Capitais - Lei n. 6.385/76. São Paulo: Quartier Latin, 2015. p. 17-24.

WALD, Arnoldo. "A reforma da lei das sociedades anônimas: os direitos dos minoritários na nova Lei das S.A.” In: LOBO, Jorge (coord.). Reforma da lei das sociedades anônimas: inovações e questões controvertidas da Lei n. 10.303, de 31.10.2001. Rio de Janeiro: Forense, 2002. p. 219-247.

WEDDERBURN-DAY, Roger. Disclosure and due diligence in the international capital markets. Bristol: Jordan Publishing Limited, 2014.

WELLISCH, Julya Sotto Mayor. Mercado de capitais: fundamentos e desafios. São Palo: Quartier Latin, 2018.

WELLS, Harwell. The rise of the close corporation and the making of corporation law. In: Berkeley Business Law Journal, vol. 5.2, 2008, p. 263-316.

WINTER, Jaap. "Chapter 1 - The Need for a Regulatory Framework: EU Company Law at the Cross-Roads". In: FERRARINI, Guido. HOPT, Klaus. WINTER, Jaap.

WYMEERSCH, Eddy. Reforming Company and Takeover Law in Europe. Oxford: Oxford University Press, 2004. p. 3-20.

WORLD FEDERATION OF EXCHANGES. Annual Statistics Guide (2018). Disponível em: https://focus.world-exchanges.org/statistics/articles/annual-statistics-guide-2018. Acesso em: 02 dez. 2019

WYMEERSCH, Eddy. "Chapter 3 - Modern Company Law-Making: about techniques of regulating companies in the European Union”. In: FERRARINI, Guido. HOPT, Klaus. WINTER, Jaap. WYMEERSCH, Eddy. Reforming Company and Takeover Law in Europe. Oxford: Oxford University Press, 2004. p. 145-175. 